\title{
Prolonged Lifetime Employment and Flexible Transition from Labour Force Participation to Retirement in View of Future Requirements of the Labour Market and Old Age Pensions*
}

\author{
by Jürgen Kruse and Werner Steinjan **
}

\section{Introduction: Why this study}

The drop in the birth rate in the Federal Republic of Germany has been discussed with increasing intensity since the beginning of the nineteen-seventies. This is understandable, since the net rate of reproduction ${ }^{1}$ which indicates whether a population is biologically increasing, decreasing, or remaining constant, changed from 1.1 in 1960 to over 1.2 in 1965 , and from 1.0 in 1970 to 0.6 in 1985 . Since the beginning of the nineteen-eighties, the willingness to bear the consequences of this development has increased among the public. The Official Statement of the Chancellor of the Federal Republic of Germany ${ }^{2}$ issued on March 18, 1987 mentioned that new measures had to be taken for the Federal Government's Old Age Retirement Plan: demographic developments have made a reform of the structure of the Old Age Retirement Plan unavoidable. An appropriate allocation of additional expenditure was discussed, as well as, in particular, better opportunities for increasing the length of lifetime employment.

* This study was commissioned by the Geneva Association and is a part of an extensive international research project on the possibilities for the gainful employment of the elderly as a part of old age insurance in the light of demographic developments. The original German version, "Verlängerung der Lebensarbeitszeit", has been published by VVW Karlsruhe, 1988.

** Dr. Jürgen Kruse was born in 1959. After completing his law degree, he assumed a position as staff assistant to the Chair of Labour Law and Social Security, under the direction of Professor Dr. Bernd Baron von Maydell. His primary area of research is the legal aspects of the Federal Old Age Retirement Plan in the Federal Republic. Mr. Kruse has been also working on his dissertation in the area of company pension plans, which will be completed in the near future. Since 1987, Mr. Kruse has been a legal assistant at the Federal District Court in Cologne.

Dr. Werner Steinjan, born in 1919, holds a degree in Economics and is a retired high civil servant. After studying Economics in Rostock and Hamburg, Mr. Steinjan became Director of Studies at the Evangelical Academy in Loccum, and Social Affairs Expert of the protestant Church in Rhineland. From 1960 to 1984, he was a civil servant at the Federal Ministry of Economics in Bonn. As division leader, Mr. Steinjan was responsible for Welfare and Labour Market Policy.

1 This indicates the extent to which the females of a population will be replaced by their (female) offspring, under given birth and death rate probabilities. A net rate of reproduction equal to 1 means that the population is remaining biologically constant. A value greater than one means that it is growing, a value smaller than one means it is shrinking. Cf. Statistisches Bundesamt (1985), p. 92.

2 Cf. Bulletin der Bundesregierung Nr. 27/211. 
In contrast to this suggestion, since the beginning of the nineteen-seventies there has been a trend towards premature work force exit in the Federal Republic. ${ }^{3}$ The percentage of males born in 1913 retiring between ages 50 and 59 was only 17.8 percent ; for those born in 1919 , this increased to 22.3 percent. Calculations of one of the insurance underwriters in the Federal Republic, the Bundesversicherungsanstalt für Angestellte (BfA), start with the assumption that for those born after 1919 , the corresponding share will be 25 percent ${ }^{4} \mathrm{~A}$ comparison of these birth years reveals that the share of 60 -year-olds entering retirement increased from 5.3 to 12.0 percent. For those born between 1919 and 1924 , this figure is expected to double to 24 percent.$^{5}$ Because of the different legal regulations with respect to retirement ages (Cf. Par. 1248, Section 3 RVO / Par 25, Section 3 AVG), this trend is perceptible to an even greater extent among females. ${ }^{6}$ If this continuing trend to early retirement is not reversed, both the labour market and the Federal Government's Old Age Retirement Plan will face problems practically without solution.

It is surprising to see how public discussions emphasize the financial restructuring of the Old Age Retirement Plan while giving only glib consideration to the need for an improvement in the real fundamental relationships of old age insurance and, indeed, of social security programmes in general. In this context, "fundamental relationships" refer to the numerical relationship which exists between those members of the labour force who are bearing the financial burden of the social security system and the recipients of transfer payments. Transfer payment recipients also include persons provided for within the family (primarily children). This relationship is determined by the time or age of entry into the labour force, by the percentage of persons of working age in the labour force, and by the age of exit from the labour force. Labour force immigration and emigration are also relevant. The total financial burden for all welfare benefits including the indirect ones within the family can be derived from this relationship. This general relationship may also be restricted to indicate the financial burden of the working population with respect to those social benefits accruing exclusively to the elderly. This is expressed by the ratio of members of the population over age sixty to those between ages twenty and sixty. ${ }^{7}$

3 This trend has also been observed internationally. On this trend in general, and in connection with unemployment, cf. Salowsky and Seffen (1986); the general development in the Federal Republic, cf. Schüle (1988), pp. 8-15; also cf. Hain (DRV 1986), p. 213.

${ }^{4}$ Cf. Bäcker / Steffen (1988), p. 158.

5 Ibid.

6 54 percent of females born in 1920 entered retirement before they turned 62 ; Cf. Kaltenbach in Schmähl (1988), p. 102 ff. (105).

7 An explanation of terminology is necessary at this point. The Youth Quotient is expressed as the ratio of the population under age 20 to the population between ages 20 and 60 . The Elderly Quotient is expressed as the ratio of those members of the population over age 60 to those between ages 20 and 60 ; Cf. Bäcker/Steffen (1988), p. 92 ff. In addition to these two ratios, terms such as Pensioner Quotient and "Pension Case" Quotient exist. For a definition of these terms, cf. Niemeyer (B 35/87), p. 20. Crucial consideration must certainly bc given to the burden of those actually in the labour force (including those members under age 20 and over age 60 ) relative to those who are not included in labour force calculations, as the financial burden stems from the latter sector of the population. With regard to future developments, one must impose certain constraints on the model and define the length of labour force participation by a predetermined age of retirement, otherwise calculations using these models are rendered mathematically impossible. Schmähl (DRV 1987, p. 3) shows the necessity and usefulness of such model specifications with respect to differing national circumstances. For this reason he views the Elderly Quotient as decisive. 
This burden must remain tolerable, if future generations are to remain willing to support a system which relies on long-term commitment to meet long-term claims. The socalled "generational contract", which forms the financial support for the pay-as-you-go system of the Federal Government's Old Age Retirement Plan, cannot be based on the impossible. It must remain within the realm of feasibility and reason. Consequently, the regulations of the Old Age Retirement Plan must be analyzed and set up considering the entire society and national economic conditions. They must be seen within the global framework of all transfer payments, for instance even those for health care, and of all government transfers, for instance those resulting from new environmental policies. Likewise, economic components, such as the prerequisites for economic growth and the development of the labour market, must also be taken into consideration.

In estimating models of future developments and the opportunities and necessity for a reform of the Old Age Retirement System there are differing degrees of forecast probability. Assumptions on the development of birth and death rates have the highest degree of probability. Forecasts which focus on other parameters such as immigration and employment rates are much more uncertain: migration factors also depend to a large extent on future immigration policies and employment rates. No less difficult is the estimation of employment rate development, especially female employment rates. The only model components which can actually be influenced are the preconditions for what, in the last analysis, are individual decisions regarding participation in the labour force. It must be underscored that the size of the female employment rate has substantial influence on the birth rate. Thus an increase in the female rate of employment may have long-term negative effects for the balance of burden-sharing.

The future deficit of labour force members cannot be fully compensated for by immigration alone or by an increase in the female rate of employment. The remaining difference must be covered through an increase in the retirement age. Only then can the necessary employment rates for the total population be reached which would improve the relationship between those members of the labour force contributing to the Old Age Retirement Plan and the recipients of transfer payments (real fundamental relationship) from this system.

The objection that high unemployment rates will necessarily result over a long time period and that therefore, for employment policy reasons, an extension of the normal retirement age is not feasible, would only be correct if it were not possible to

- break through the "labour blockade" which arises through increasing regulations and a collective bargaining policy which ignores prevailing market conditions;

- achieve a differentiated retirement age based on market conditions. In reality, we shall always have a split labour market, i.e. there will always be persistent unemployment in the semi-skilled or unskilled sector (with too high wages in relative terms) and increasing shortages of labour in the skilled sector, in which a balance can only be achieved through longer employment, not through further qualifications.

This study addresses these questions and problems. The model presented here aims at reducing the burden of the elderly on current generations by lengthening the duration of labour market participation. Proposed is an increase in the total employment rate, achieved via an increase in the employment rate of the elderly. This goal should be attained by a 
combination of raising the Normal Retirement Age (NRA) and allowing for flexible transitions from employment to retirement. The individual consequences of this suggestion could be viewed as "severe" and "socially unbearable". The response to this criticism, however, is that the burden of responsibility on future generations must equally remain "socially bearable".

The authors are aware that there are other possible solutions to the intergenerational problem of caring for the elderly. These include the introduction of flexible retirement ages with actuarily justified credits or reductions in benefits. The problem with this suggestion, however, is that necessary improvements in the fundamental relationships- and the equilibrium of the system as a whole - can be jeopardized as a result of individual decisions. Therefore, the Normal Retirement Age must be shifted from age 65, the present level, to age 67 and, likewise, the conditions for receiving disability pensions must be tightened if the necessary burden relief is to be realized. To make matters worse, only highly qualified persons are able to make decisions regarding private insurance plans, and those persons are the ones in whom private pension plans show special interest. A dilemma then emerges between the desirable freedom of individual decision and the needs of the society as a whole.

\section{Demographic development and its implications}

\subsection{Evolution and current situation of population development in the Federal Republic}

\subsubsection{Current population structure}

The size of the present population as well as its relevant structural characteristics, such as age, sex, and the proportion of foreigners etc. are presented in this section; as of December 31, 1986, the Federal Republic of Germany had 61,140,500 inhabitants. Of these, $4,661,900$ were foreigners. Within the German population, there were $26,747,500$ males and $29,731,100$ females. ${ }^{8}$ These statistics, including those in the cross-sectional composition of the population, vary little from those used as the basis for the 1987 report prepared by the Verband Deutscher Rentenversicherungsträger (VDR-Gutachten).

Even though the official statistics mentioned above lead to a relatively more optimistic forecast for the year $2030,{ }^{9}$ the data used by the VDR Commission ${ }^{10}$ will be used throughout this study.

The following old-age pyramid ${ }^{11}$ clearly portrays the decline in birthrates which began in the middle of the sixties and which was most pronounced in the seventies. This decrease came to a halt around $1979 .{ }^{12}$ It is important to note that virtually nothing has changed since

\footnotetext{
${ }^{8}$ On these statistics cf. Proebsting (1988). p. 60.

${ }^{9}$ For the German component of the population this amounts to a difference of 1.15 million people compared with the results obtained using December 31, 1984 forecasts. Cf. Proebsting (1988), p. 63.

${ }^{10}$ Population extrapolation of the Statistisches Bundesamt; sample taken on December 31, 1984; Cf. VDR-Gutachten, p. 15.

11 Refer to Figure 1.

12 Grohmann (1985), p. 29.
} 
then with respect to the age and frequency of child-birth per female. ${ }^{13}$ Moreover, a further shift upwards in child-birth age can in any case be ruled out. Therefore, a current and future net rate of reproduction of 0.6 can be assumed.

The historical development of the mortality rate is also of interest. It can be seen here that the trend - albeit gradual - is towards a longer life-expectancy for males as well as for females. This implies, of course, that the mortality rate is declining. About one hundred years ago the average life-expectancy of a new-born was 35 years. Now this figure has risen to 71 years for males and 78 years for females. ${ }^{14}$ Of even greater importance for old age retirement plans is the consideration that 60 -years-old males are expected to live another 17 years and 60-years-old females another 21 years. ${ }^{15}$

The development of the upper age range of the population, i.e. those over 90 years, is particularly striking. In 1885 , for every 100,000 inhabitants of the German Reich, only 17 were over 90. In 1986, according to microcensus data of the Statistisches Bundesamt, this number had increased to 300 . As late as 1950 , the number of nonagenarians was only $20,000 .{ }^{16}$ The total number of persons over 90 living in the Federal Republic as of 1986 was 188,700 . Of these, 143.000 were females.

Considering this, it is no surprise that the ratio of work force participants relative to total inhabitants was only 45.2 percent in 1984 - an important factor in financial considerations of the social insurance system. ${ }^{17}$

The number and sex of foreigners within the Federal Republic are important aspects in describing the structural composition of the population. As of December 31, 1986, there were 4,661,900 foreigners living in the Federal Repulic, with more males (approx. $2.54 \mathrm{~m}$ ) than females (approx. $2.12 \mathrm{~m}$ ). Their age structure too differed substantially from that of the German population: 40 percent of the foreign population was between ages 20 and 40 as compared to 30 percent for the German population. Less than 25 percent of the foreign population was over 40 , while approximately 50 percent of the German population fell into this category. ${ }^{18}$

\subsubsection{Structural development of the population}

Insofar as future developments are concerned, it should be stressed here that the task of this paper cannot and should not be to present an original population model. For this reason, this study relies heavily on the calculations derived from models used in the VDR Commission studies. ${ }^{19}$

\section{${ }^{13}$ Ibid.}

${ }^{14}$ Lehr (1988), p. 10 (Column 1).

${ }^{15}$ Lehr (1987), p. 176; Cf. VDR-Gutachten, p. 20, for appropriately amended mortality tables from 1972/4 and 1982/4; Cf. Müller (DRV 1987), p. 30 ff. Müller shows here that these numbers represent only statistical averages in international comparisons.

${ }^{16}$ Statistics taken from the Frankfurter Allgemeine Zeitung, March 2, 1988, p. 10.

${ }^{17}$ Cf. Bundesminister für Arbeit und Sozialordnung (1987b), Table 2-3.

18 Cf. Proebsting (1988), p. 62 ff., where a convergence of these two sub-structures is assumed to occur by the year 2030 .

${ }^{19}$ This is the model which is referred to in the following analyses unless specified to the contrary. 
Figure 1

Cross-Sectional Population Profile

- Age Structure -

\section{Age in Years}

Males

Females

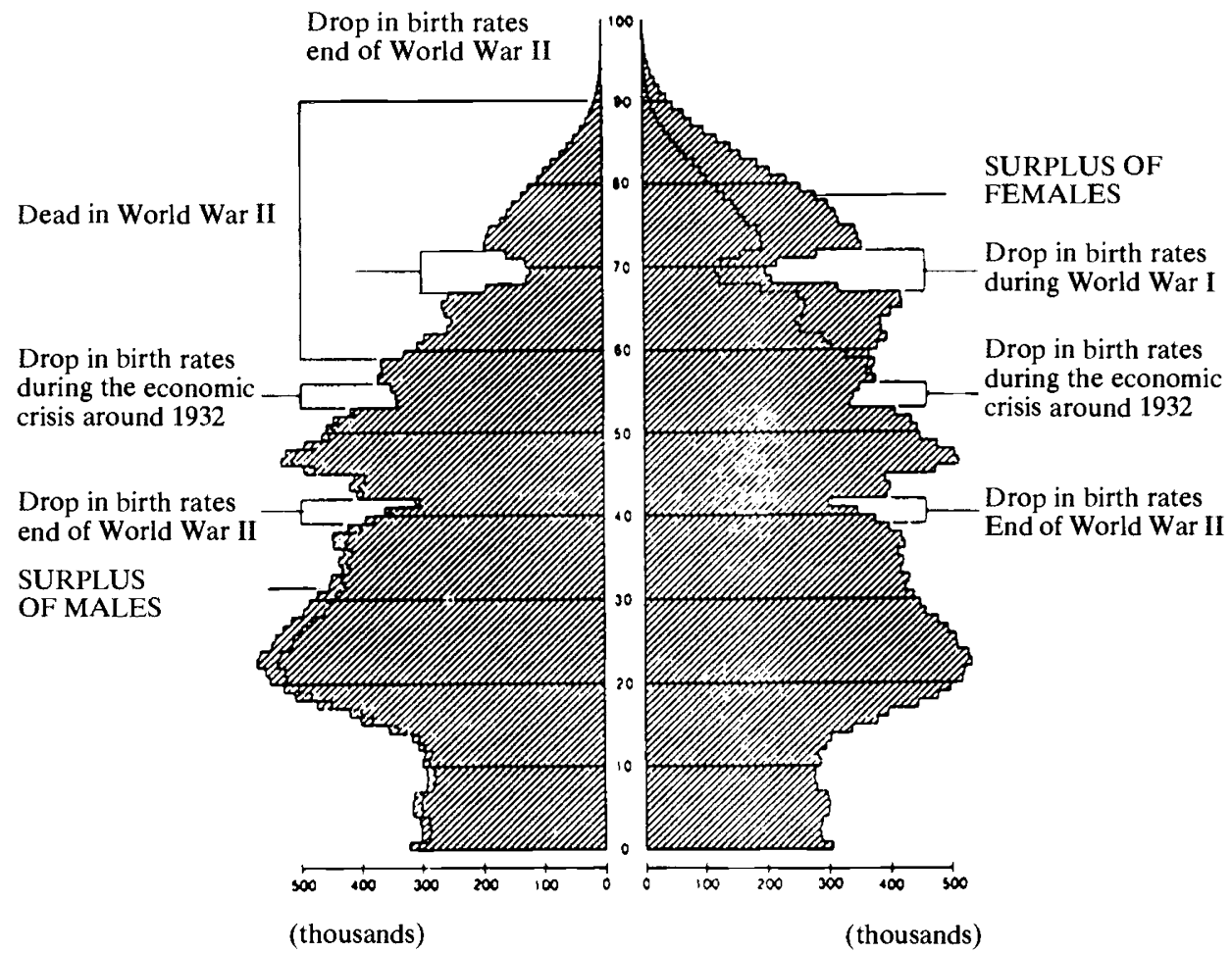

Source: Statistisches Bundesamt 1988. 
2.1.2.1. a) Up to the year 2030 , a population contraction to approximately 46.5 million inhabitants is expected. ${ }^{20}$ This assumption is based primarily on the observation that the net rate of reproduction sank to 0.6 in the period up to 1985 and has remained at that level ever since.

On the basis of numerous factors (which will not be elaborated at this point), it will be generally assumed that no changes in the birth rate can be expected..$^{21}$

b) It is even easier to accept the assumption that there will be no substantial changes in mortality rates. This stems from the fact that the uncertainty in this area is less than that in the development of the birth rate statistics. Therefore, it is seen as highly probable that life expectancies will continue to increase in the future. 22

c) Estimates of the probable development of immigration also present large problems. The immigration and emigration of foreigners is to a large extent contingent on the differences in economic development between the countries of origin and the Federal Republic. ${ }^{23}$ Additional model uncertainties stem from the political situation in the respective countries. The VDR Commission brings forth the example of the effects of the Promotion of Re-Emigration Law (Rückkehrförderungsgesetz) as well as the then-unpredictable stream of those seeking political asylum. ${ }^{24}$ In this context, treaty negotiations with Turkey cannot be reliably estimated at this point in time..$^{25}$

Prognos Institute estimates, in a "high" scenario of economic development, assume a positive immigration balance of approximately 30,000 per year between 1990 and $2040 .{ }^{26} \mathrm{~A}$ "low" scenario contains estimates of a negative annual immigration balance of 40,000. Furthermore, it is assumed that the surplus of German immigrants (in particular from Eastern Europe) will decrease to zero by the year 2010 .

In the light of all this, the present study is based on the assumption that the decline of the German population will not be significantly compensated for by the immigration rate.

20 Results from other Institutes should be considered here, as they vary substantially:

- 48.5 million, from an updated IC Model report on the population from the Federal Government, cited in Niemeyer (B 35/87), p. 20, Table 3;

- Approximately 49.3 million based on population and birth rates in 1986, according to the Statistisches Bundesamt, cf. Proebsting (1988), p. 63, Tables 4 and 5;

- Circa 50 million, according to the Prognos report in its high-estimates case. By contrast, the VDR Commission bases its estimates on the low-estimate scenario.

21 In this context, Wingen (1988) refers to the limited ability of governmental intervention in the short to medium term to induce a major change in the reproductive behavior of the population. In other words, Child Support Funds provide no panacea.

22 Cf. Prognos Report (Prognos-Gutachten) (1987), p. 13, with reference to most recent model results from the Ministry of the Interior in Footnote 1.

23 Ibid., p. 13, left column.

24 VDR Report (VDR-Gutachten), p. 22; the structural age convergence of the German and foreign population sectors in the Federal Republic has already been mentioned; cf. Proebsting (1988), p. 62 .

25 Cf. Prognos Report (1987), p. 13, Footnote 2.

26 Ibid., p. 16. 
2.1.2.2. In the following section, the model assumptions are discussed which pertain to the development of the age strata up to 2030 .

The number of persons under age 20 will decrease from its current level of approximately 13.5 million (Germans and foreigners) ${ }^{27}$ to between approximately $7.2^{28}$ and 9 million. ${ }^{29}$ By 2030 a reduction of about 30 percent will be observed in the 20 -to-59 age group. This represents a decrease from its current level of about 34 million persons to about 22 million persons. By contrast, the number of persons 60 years of age and older will increase by approximately one-third, from the current level of about 12.5 million persons to about 17.5 million persons.

To clarify the above figures: for every three persons aged between 20 and 60 , there is currently one person over 60 ; by 2030 , this ratio will be approximately 1.25 to 1 .

\subsection{The implications}

The consequences of these statistics will be presented in this section. Because future consequences will show up primarily in the labour market and thereby play a significant role in future economic development, this aspect will also be included in the following discussion. Finally, the implications for the Federal Old Age Retirement Plan will be considered on the assumption that the current legal situation will not change substantially.

\subsubsection{Implications for the labour market and the economy}

The development of the labour market in the Federal Republic has been shaped by strong demographic influences since 1950. The first development phase, from 1950 to 1960 , was influenced by a large increase in the number of potential labour market participants of approximately 5 million persons. This was primarily a result of the massive influx of millions of exiles and an additional 3 million refugees from Soviet-occupied area and the German Democratic Republic. In contrast to later waves of immigrants, the immigrants in this phase were well-educated and accustomed to a highly industrialized society. This provided a substantial surplus of "human capital", which was an important requirement for the Marshall Plan and the introduction of the social market economy. The results were what has subsequently been termed the German Wirtschaftswunder (economic miracle). In spite of this population expansion, labour market statistics show a decrease in unemployment from 1.9 to 0.3 million in that decade.

In the full employment phase which followed from 1960 to 1973, the number of potential German labour market participants decreased by 1.4 million due to increases in the length of formal education and on-the-job training programs, and to the lowering of retirement age. This decrease was more than compensated for, however, by the immigration of more than 2 million foreign workers. This immigration reached a peak in 1973, when 2.45 million workers in that year alone arrived in the Federal Republic. In this phase the German economy once again had at its disposal virtually unlimited labor market reserves; so much so, that the expansion knew almost no quantitative limits. The qualitative contrast with the

\footnotetext{
27 These values are taken from the updated Tables 4 and 5 in Proebsting (1988), p. 63.

28 Assumption of the VDR Report, p. 35. Diagram11.2.

${ }^{29}$ This value is taken from the high-estimate scenario by Prognos AG; in the low-estimate scenario, calculations indicate approximately 8.2 million; Cf. Prognos Report (1987), p. 23, Table 3-1.
} 
first phase was, however, considerable. This was due to the fact that the immigrants were mostly unskilled and came primarily from non-industrial economies. This has without a doubt had implications for the German economy, not the least of which are delays in structural change up to the present time.

Beginning in 1973 with the oil crisis and the collapse of the Bretton Woods System, new labour market tendencies became noticeable. These tendencies were marked by the labour market policy of no longer accepting non-EEC workers. In the phase which followed - that in which the German economy finds itself at the present time - German labour market reserves have increased by approximately 2 million persons; those of foreign inhabitants, on the other hand, have decreased by about 0.4 million persons. This increase is now expected to stop as a consequence of the demographic development. In this last period persistent unemployment has developed, with a base of over 2 million persons and a hidden reserve which the Federal Employment Agency (Bundesanstalt für Arbeit) estimates at approximately 1.3 million persons. Two-thirds of this increase can be attributed to the overall increase in labour market reserves; one-third, however, is attributed to economicinduced job cut-backs. The increase in labour market potential means that in spite of intermediary business cycle boom phases (1978 to 1980 , and 1983 to the present), the unemployment base cannot be eliminated.

A new phase in the development of the labour market will come into existence at the beginning of the next decade as a result of demographic developments. This phase will be marked by a continuous decrease in potential German labour market participants.

The economy and the labour market will have to adjust to new conditions. It will no longer be possible for an economy such as the Federal Republic, which realizes rapidly increasing rates of technological progress, to mobilize a sufficient number of qualified domestic workers as it has in the past. An excessive demand for skilled workers will first be observed which will gradually also extend to graduates towards the end of the nineties. Based on the experiences from the mid-sixties to the seventies, this deficit cannot be simply counterbalanced by hiring foreign workers. Thus the implications of the changing structure of the population will first be seen in the labour market.

The question of the quality and quantity of this development has been considered for some time by the Institute for Labour Market and Occupational Research of the Federal Employment Agency (Institut für Arbeitsmarkt- und Berufsforschung der Bundesanstalt für Arbeit (IAB)). Parallel to and in cooperation with this Institute, other economic "thinktanks" have also addressed this issue (DIW, Berlin; Ifo-Institut Munich; RWI Essen; and Prognos AG, Basel). The two scenarios of the Prognos Report include estimations of labour market potential in the year 2000, 2015, 2030, and 2040. ${ }^{30}$ The results do not differ substantially from those of the IAB, which are discussed below. ${ }^{31}$

Model estimates of future labour market developments are largely determined by a "basic trend" induced by structural changes in the population (presented above) and expected population evolution in the near future. These estimates are also, however, significantly influenced by two other variables; the labour force quotient, especially that of the female component of the population, and the immigration factor.

\footnotetext{
30 Prognos AG (1987), p. 25, Table 3-3.

31 The following explanations are based primarily on Klauder (1988a).
} 
The development of the female labour force is difficult to estimate, even if a general increase is assumed ${ }^{32}$ After all, only the preconditions for individual decision regarding labour market participation can be influenced. Improved education and successful methods of integrating women into the work force after the child-rearing years are over could prompt more women to decide in favour of employment. It should be noted, however, that the female labour force participation rate also influences the birth rate. Therefore, increasing the labour force participation rate could have long-term negative implications for the old age insurance system.

Disregarding immigration and emigration, the potential labour force, which should increase slightly until the end of the decade, will experience an overall decrease of approximately 1.7 million workers by the year 2000 . A further increase in female employment and a positive immigration balance could offset this decrease; in extreme cases, it could overcompensate it.

In the next decade, however, a considerable quantitative change in potential labour market resources does not appear probable. The increase in the labour force ratio as well as a net immigration rate which are generally considered possible, will, however, be influenced by economic developments about which it can only be speculated. Likewise, it is difficult to forecast future foreign labour policies, some of which are presently in the planning stage. The decrease in the labour force stemming exclusively from developments in birth and death rates - regardless of compensation through the two other variables - will undoubtedly have qualitative consequences. The economy will face other substantial problems, different from those encountered during the full-employment period, but also between 1973 and the end of the eighties. The already noticeable dearth of persons entering on-the-job training programmes, especially in industry, and to a lesser extent in the service sector, is a sign of these developments. Merely quantitative exploration of this problem would therefore be insufficient.

The IAB, in collaboration with the Prognos Institute, has published labour market demand growth scenarios up to the year 2000 using different assumptions. The worst-case scenario, which assumes a real growth rate of 1.0 percent foresees a decrease in the number of labour market participants of approximately 2.5 million. In the intermediate case $(2.5$ percent real growth rate), the number remains constant, and in the best-case scenario (real growth rate of 3.0 percent), an increase of approximately one million persons is expected. In comparing these figures with actual developments subsequent to the model estimation, it appears striking that in spite of a low growth rate of 1.7 percent in 1987, (1985: 2.0 percent and 1986: 2.5 percent), the actual number of labour force participants lies well over the status quo number assumed in the model computations. This means that these model estimates should not be misunderstood as forecasts. Even with this restriction, however, it should be noted that every model alternative shows a substantial unemployment rate until the year 2000 . Even with favourable data combinations, the number of the unemployed decreases to just under one million persons.

32 This issue cannot be analysed in greater depth here. Cf. results of the Sozialpolitische Kolloquim der BfA (April 28/9, 1988) in Berlin. Short summaries of the presentations are available. 
Acceptance of these results implies that the unemployment rate must be considered an important factor in strategic discussions until the year 2000. For the year 2000 and later, due to the long forecast horizon, constant labour force participation rates and equal emigration/ immigration rates are the only realistic estimates which can be employed in model estimates. Even these restrictive calculations result in some variation, as it is improbable that the birth rate would remain constant over such a long time. A birth rate allowed to fluctuate within a given narrow range, produces a variance of approximately five million labour force participants. Depending on the model alternative (large city or rural community), the reduction in the potential labour force would be between 0.7 and 0.8 percent, 1.2 and 1.3 percent, and between 1.9 and 2.0 percent in the first, second, and third decades, respectively. This considerable decrease in labour market potential, even within these small ranges (which involve approximately eight million persons in the best case, and approximately thirteen million in the worst case), shows that the consequences of the demographic development over the next decades are also a qantitative problem.

Considerable increases in the female labour market participation, which would amount to an additional three million females if the labour force participation rate were equal to that presently experienced in Sweden, ${ }^{33}$ would nevertheless be able to compensate for only one-third of the decrease caused by demographic conditions. Possible role conflicts in this case might be avoided through a substantial change in the structure of the labour market in favour of part-time employment. Compensation via immigration merits only limited consideration due to already existing problems of foreign workers integration. The largest compensation must therefore be realized through increased employment of the elderly. Similar to the proposal to increase female labour force participation rates, this proposal requires a substantial increase in the number of part-time jobs.

The potential for economic growth is derived from changes in the potential labour force and in its productivity. A decrease in the labour force potential can, therefore, be offset by growth in productivity. Assuming that a decrease in the potential labour force is unavoidable, a constant annual growth in productivity of 2 percent must be achieved to compensate for this decrease. Considering the long-term decrease in productivity growth rates, this suggestion is dubious at best. ${ }^{34}$ These rates have decreased since 1960 : production per man-hour has decreased from 5.1 percent during 1960 to 1965 to 2.2 percent during 1980 to 1985 . Over the same time span, productivity rates (measured as output per worker) decreased from 4.3 percent to 1.8 percent.

In addition, there are shortage problems which cannot be solved by increasing productivity. The lack of weekend economic activity, especially in the service sector, provides a key for analyzing future problems.

A continuously weak rate of overall economic growth in the long term would pose problems for the business sector, for society in general, and not least, for the welfare system. A stagnating economy means a lack of investment initiative in technological progress. Technological progress is crucial for an economy such as that of the Federal Republic, which relies heavily on raw material imports. All changes resulting from internal contraction, on the one hand, and from supposedly dynamic rest of the world, on the other hand,

\footnotetext{
${ }^{33}$ Klauder (1988b), p. 14, Manuscript.

${ }^{34}$ Cf. Bundesministerium für Wirtschaft (1987), table 1.
} 
are easier to manage with strong economic growth, just as developments in the wrong direction are easier to correct. An additional consideration is that the exceptional problems of Less Developed Countries (LDCs) in the future will pledge all industrialized nations and in particular those which are highly developed, to come heavily to their assistance. The theoretical alternative of resignation cannot therefore be seriously considered within the framework of the practical policies of the coming decades. Long-term continuous economic growth must remain a priority - also for the Federal Republic. On these grounds too it is necessary to consider alternatives for lengthening the years of labour force participation.

\subsubsection{Implications for the Federal Old Age Retirement Plan}

In this section, the consequences of the demographic developments presented above for the Federal Old Age Retirement Plan will be examined.

2.2.2.1. In order to gain grounds for comparison to present day conditions, it will be assumed in subsequent analyses that laws presently in effect will not be changed substantially in the future. ${ }^{35}$ It will also be assumed that there will be no changes in the financing methodology, i. e. payroll contributions, limited federal tax support, and a pay-as-you-go institutional structure will continue into the future. Furthermore, in the analyses which follow, the present system of pension adjustments as well as changes in federal government contributions, which are contingent on the average before-tax wage or salary of a "covered" employee ${ }^{36}$ will also remain unchanged. Additional considerations include the present procedure for adjusting the contribution rates for the Federal Old Age Retirement Plan and the 50 percent subsidy of the Federal Health Insurance Program for the elderly by the Federal Old Age Retirement Plan. Finally, it is assumed that equivalent payments into the Old Age Retirement Plan for child-rearing years will continue to be the responsibility of the Federal Government. ${ }^{37}$

2.2.2.2. In order to emphasize the need for compromise regarding longer labour force participation, ${ }^{38}$ it is sufficient simply to refer to the evolution of the contribution rates in light of the model restrictions mentioned above. Reducing benefits to approximately half their present levels is ruled out a priori on political grounds. ${ }^{39}$

From 1959 to 1987 , the contribution rate increased by 4.7 percent, from 14.0 to 18.7 percent. Model scenarios for a period just half as long, from the present to the year 2000 , forecast a further increase of 5.0 percent (to 23.7 percent). Even the best-case scenario

35 This procedure is common to the literature; Cf. Meinhold (1985), p. 16; VDR Report, p. 55; and Prognos Report (1987), p. 57; Grohmann (1985), p. 32 ff. employs another methodology which is based on group simulation models.

${ }^{36}$ For further discussion on this matter, cf. VDR Report, p. 60, in which it is assumed that the portion of financing supplied by the Federal government will decrease to 12.5 percent by the year 2015 .

${ }^{37}$ It cannot be and is not the intent of this study to include every real-life situation and condition in the model presented here. For model elaborations, cf. VDR Report, p. 55 ff, "Zur weiteren Finanzenentwicklung der gesetzlichen Rentenversicherung unter Status-quo-Bedingungen".

${ }^{38}$ It should be noted that the question of the effectiveness of such measures is not addressed here. This issue is deferred to Part Two, I. B.3.2.

${ }^{39}$ Cf. Arbeit und Sozialpolitik (1987), p. 107 ff. (108). 
predicts a 3.5 percent increase (to 22.2 percent). ${ }^{40}$ This development will continue even more rapidly between 2000 and 2015 , with the contribution rate increasing by 4.8 points in the "best-case" scenario (to 20.0 percent) and by 5.3 points in the worst-case scenario (to 29.0 percent). By 2030 , the contribution rates in these two scenarios will have increased by 9.4 points, to a 36.4 percent level, and by almost 11 points, to a 40.1 percent level respectively.

No further explanation is necessary to show that for the insured such a burden is simply unrealistic. No substantial changes can be made here even if one considers reducing benefits in other areas, such as those for war victims or the unemployed. ${ }^{41}$

In summary, the implications of demographic development for the Federal Old Age Retirement Plan show ceteris paribus the necessity for immediate legislative action.

It has already been emphasized that lengthening the years of gainful employment is not fully sufficient to solve all problems. However, a considerable number of institutions ${ }^{42}$ and authors ${ }^{43}$ view it as a significant possibility to counteract the increase in the financial burden on both employer and employee which would arise from increasing contribution rates. One of these authors mentioned as early as in 1981 that a compensation for the fundamental relationship can be achieved not only by modifying the level of retirement pensions and of retirement contributions, but also by changing the fundamental relationship itself. One could relieve these burdens, which are now seen as unbearable, with variations in all relationships. "It is possible that the retirement age in the foreseeable future will be increased, and that at the same time employment disability payments and early retirement pensions will be made more difficult to obtain. The time of entrance into the labour force, on the other hand, can probably not be manipulated in such a way as to provide significant burden relief." The following section presents possible alternatives for lengthening the period of employment, considering the mainly legal constraints but also the basic objections of those who must ultimately finance the benefits to be received from the Federal Old Age Retirement Plan.

\section{Prolongation of lifetime employment}

\subsection{Opportunities for prolonging lifetime employment}

There are two ways in which the length of labour force involvement ${ }^{45}$ could naturally be increased. First, measures could be introduced which would reduce the average age at

40) These values assume that the contribution rates to the Federal Health Insurance Programme wil not change; Cf. Prognos Report (1987), p. 61, Table 5-3.

41 There is obviously a conflict here which results from an isolated consideration of the demographic evolution. This method of examination fails to consider both the consequences of economic growth and the effects on the welfare system as a whole. Cf. Schmidt (DRV 1988) p. 24 ff.; ibid. (DRV 1987) p. 500 ff.; VDR Report, p. 219 and Prognos Report (1987) p. 5.

42 For example, according to the Prognos-AG, p. 88 increasing the age of retirement is significant only in the best-case scenario. This is contingent on arguments of effectiveness which are explored in a later section; also cf. VDR Report o. $170 \mathrm{ff}$.; and EKD-Denkschrift, p. 71, line 92.

${ }^{43}$ Schüle (1988), p. 21 with further references; for a more cautious, yet still positive representation, cf. Hains (DVR 1986), p. 213.

${ }^{45}$ It is tacitly assumed that this is to be understood in the context of this study to mean an extension in the number of working years covered by thc Federal Old Age Retirement Plan. 
which an employee covered by the compulsory insurance scheme enters the labour force. Second, the boundaries at the other end of the scale can be extended by increasing the average age of retirement.

\subsubsection{Opportunity for influencing time of labour force entry}

3.1.1.1. If an early entry into the labour force is a goal, then it must be achieved at the cost of reduced education time. Fortunately, the number of young people entering the work force without completing some sort of education is constantly decreasing and in the future this number is expected to decrease even more. ${ }^{46}$ The number of younger persons who are neither in a profession nor working towards one and who are not registered as "unemployed" will also comprise a much smaller portion of the population in the future. ${ }^{47}$

The term "training time" reflects distinct educational and professional training phases: a) Possibly also due to the apparent unemployment among the young in the seventies, attempts were made to raise the number of years of obligatory education and to keep young people in some sort of vocational or other school for as long as possible. The average time required for graduation from the Hauptschule is, as a rule, ten years. ${ }^{48}$ Until the beginning of the seventies, however, the tenth year of schooling was not obligatory. ${ }^{49}$

It remains to be seen if it is possible to return to the legal stand of the past. This is the direction in which the foregoing discussion may proceed. It should not be overlooked that in such considerations, an examination of the educational content and goals of the Hauptschule is relevant.

b) Reducing the actual period of vocational training is not feasible in the light of rapidly rising job requirements resulting from technological progress. Therefore, this alternative merits little discussion.

c) The situation looks different from the perspective of the Gymnasium. The elimination of the thirteenth school year continues to be discussed. One factor that speaks for elimination of this last school year is that this year is, in reality, only a half year. Moreover, the syllabus could possibly be compressed in such a way up to the twelfth year as to entail no reductions in the material taught even if the thirteenth year is abolished.

d) Finally, attention should be attracted to the criticism of the long years of schooling in German colleges and universities. An important consideration here is the competitive disadvantage which the "aged" German college graduates have compared with graduates in other EEC countries. By continually rationalizing course contents, time could be saved.

46 For 1982 , Klauder (1987), p. $30 \mathrm{ff}$. calculated the size of this group to be approximately 8.2 million, which includes 1.3 million apprentices having no other qualifications and 0.4 million trainees. He expects a further decrease of approximately 3 million by the year 2000 .

47 The fact that a reduction of unemployment among young persons is an important task especially in terms of reducing the financial burden of the Old Age Retirement Insurance, needs no further elucidation. This problem, however, does not belong to those addressed in this section.

48 Cf. for instance North Rhine-Westphalia Schulpflichtgesetz, Par. 5, Section 1; the explanation which follows should be considered only as an example. An extensive examination of the situation in other Länder has been purposefully not included.

49 After the law of April 14, 1966 was passed introducing a mandatory ninth(!) school year, advanced classes were offered for an optional tenth year in 122 schools in North Rhine-Westphalia beginning on August 1, 1970. 
Certainly good job prospects in especially problematic study courses could provide the best incentive for students to finish their studies fast. Circumstances which are only indirectly connected to the study courses may play a role here. Furthermore, the increasingly greater demands, especially in technical and natural sciences fields, also limit the opportunities for shortening these studies. ${ }^{50}$ The advantages of a fundamental education - not just for the individual, but especially for society as a whole - cannot be overstated.

3.1.1.2. The discussion above should show where an extension of lifetime employment by lowering the time of entrance into the labour force may be advocated. Questions of "quantification" were deliberately not addressed in this discussion, as further amplification would inevitably lapse into speculation. The purpose was rather to clearly show that even in this area a number of supportive measures are necessary, such as the consistent evaluation of curricula, if a meaningful reduction in the mandatory length of education is to be realized. Even so, however, great expectations in this area would be misplaced.

3.1.1.3. Supportive measures in a broad sense could also include a different method of computing time out of the workforce during the education phase and recognizing it for insurance purposes as discussed in the VDR Report. ${ }^{51}$

According to law, it is possible to accumulate a maximum of thirteen years out of the workforce due to educational pursuits. This study suggests that this should be limited to nine years. Even though a direct connection is difficult to prove, the possibility cannot be dismissed that retirement laws which give preference to persons having spent longer years in education or training could conceivably strengthen the trend towards increasingly longer periods of education ${ }^{52}$ even if only to a minor degree.

\subsubsection{Opportunity for prolonging lifetime employment by influencing the time of exit from the labour force}

\subsubsection{Employment among the elderly}

\section{a. Methodolgy}

An analysis of opportunities for increasing the number of years in the labour force proceeds in two phases. First, the issue as to whether the realization of such a goal might come up against fundamental opposition from those concerned must be considered. Experience in various political and legislative branches shows that evasive measures are always introduced which then undermine achievement of the goal at hand. Essentially this is a question of population attitudes. In spite of frequently raised criticism regarding survey techniques, demoscopic research gives us an instrument with which tendencies in a sample of the population can be identified. In the following sections, questions specific to this topic will be referred to as the "demoscopic approach".

${ }^{50}$ The Minister of Education for Rhineland Palatinate, Mr. Gölter, has alluded to the role a change in major plays for many students. This "costs" in the average approximately two semesters, but is affordable in an educational system based on freedom; Cf. Article in Frankfurter Allgemeine Zeitung (14 May 1988), p. 39.

51 Cf. VDR Report p. 145; this context also cf. Doetsch (DRV 1987) p. $514 \mathrm{ff}$.

52 An extended discussion of the expected benefits accruing to contribution payers from a "new regulation for calculation and recognition of times of non-payment and partial payment of social insurance contributions" (Neuordnung der Anrechnung und Bewertung beitragsloser und beitragsgeminderter Zeiten") cannot be the subject of the ongoing discussion due to the limited nature of the subject. 
In the second phase, the question is addressed as to how the physical and psychological ability of elderly members of the population can be sustained. What findings can medicine and psychology offer here? One branch of psychology, gerontology, is concerned with this issue, especially the ability of the elderly to work. This study will therefore refer to a "gerontological approach".

Finally, the question as to whether employers find it feasible and/or useful to employ persons who are past the non-effective retirement age is of consequence. If this were not a desirable option, any strategy to increase the retirement age would have to reckon with substantial employer opposition. This discussion will be referred to as the "business sector approach".

After ascertaining that fundamental obstacles do not exist or can be overcome through appropriate measures, one can then consider problems associated with achieving the goal at hand in a more concrete fashion. This two-fold approach will be maintained throughout the following study.

\section{b. Basic impediments to prolonging lifetime employment \\ i. Demoscopic approach}

The Allensbach Institute for Demoscopy, in a population survey of January $1958^{53}$ entitled "Lifetime Labour Force Participation" attempted, among other things, to discern public attitudes towards increasing the number of years worked. The question of particular interests is quoted here in order clearly to represent the manner in which the information was obtained. The question read:

"The population in the Federal Republic is continuously decreasing, so that in the long run, there will be fewer people working and more retired people. If someone said, 'because of this, we are going to have to increase the number of years worked in the future', would you say that he was right or wrong?"

Of the total number of people questioned, 35 percent (an equal percentage of men and women) were of the opinion that the number of years spent in the labour force must indeed be increased. Moreover, 35 percent of the respondents, specially polled according to occupations were also of this opinion. The results for specific age groups are also of interest. The responses of persons in the 16 to 29 age bracket, who to a large extent do not yet belong to the labour force, were 8 percent below the average. In contrast, those persons in the 30 to 60 age bracket (who were further subdivided into three smaller groups) scored between 36 and 40 percent, i.e. fairly uniformly above average.

Forty-one percent of the total population said that it was not necessary to increase the number of years worked. What is interesting here is the sharp deviation of responses between the sexes: 45 percent of the men, but only 37 percent of the women, agreed with this opinion. The relevant percentage among the working population was approximately equal to that of the male population above, i.e. 44 percent. Clear differences existed in individual age brackets. With a deviation of $+/-4$ to 5 percent, the number of persons agreeing with this opinion decreased with increasing age from 47 percent to 34 percent.

\footnotetext{
${ }^{53}$ Allensbach-Institute (1988) IfD-Umfrage 4099 (January 1988); Cited in Der Arbeitgeber (1988), p. 240 .
} 
Thus, the number of persons in the 16 to 29 age group who where opposed to an increase in the number of years worked was clearly greater than the number who agreed with this suggestion ( 47 and 27 percent respectively). In other age categories, opinions were almost evenly divided.

Another curious result is the number of "undecided" responses. On the average, 24 percent of the total population was "undecided" on this question. Of these, 20 percent were men and 28 percent women. The least "undecided" were the 30 to 44 year olds ( 19 percent). Even the 45 to 59 year olds were below the average ( 21 percent). Those above the average were the very young (ages 16 to 29 ) with 26 percent, and the very old (ages 60 to above), with 30 percent.

This leads to two suppositions concerning the relatively high percentage of "undecided": in general, this could stem from insufficient information or (even greater) insufficient consciousness of the problem. It is also possible that among the young, the feeling of "it's not going to be $m y$ problem for a long time" and, among the elderly, the feeling of "it's no longer my problem" plays an important role.

For the age group with by far the highest percentage of labour market participants, the share of friends and foes of these two positions is approximately equal, with the number of "undecided" at approximately 20 percent. The conclusion may be cautiously drawn from the data that increasing the total length of time in the working force would not be met with formidable opposition from the population at large.

Furthermore, based on the questionnaire results, the need for information about, and consciousness of, the problem is quite clear. In the future, the financial consequences for each individual contribution payer of maintaining the status quo must be made visible to a wide spectrum of the public.

Finally, the rejection of the idea by approximately two-fifths of the population makes it clear that legal recourse - in one form or another - is essential. This is all the more important as measures affecting confidence in the pension system, which should become effective around 2010 , cannot be delayed any longer.

There is otherwise no reason to fear that insurmountable difficulties will arise from the population. Questionnaire results show that in spite of the trend to early retirement, substantial insight has been gained into the difficulties which might be expected. An explanation is necessary, however, for the public to understand why the number of labour force participation must be increased ${ }^{54}$ in addition to all other measures.

\section{ii. Gerontological approach}

Gerontologists have long maintained that unambiguous statements regarding the physical - but above all, the mental - ability of elderly persons to work can only be accurate if corresponding company-related empirical studies can be conducted. ${ }^{55} \mathrm{~A}$ number of

${ }^{54}$ That this has already been realized to a large extent by economic, political, and managerial leaders (an average of 73.8 percent), says much for the suspicion that there is still an information deficit among the population. For further details on this conclusion, cf. Allensbach survey conducted for the magazine Capital (11/1987), p. 149 ff (150). It is not surprising that within this group, the personal desire for a longer time of employment is quite marked; also cf. Footnote 53.

55 Cf. for instance Thomae / Lehr (1973), p. 76. 
indications speak, however, for the hypothesis that the "chronological age" is a relatively insignificant factor affecting the ability of elderly persons to work ${ }^{56}$ although this is not indefinitely applicable in cases of extreme old age.

During the seventies, developments in other countries occurred which could have been inconceivable in the Federal Republic - and not just for reasons related to the labour market. In the USA in April 1978, a law directed against the discriminatory treatment of the elderly was enacted. This Retirement Act declared the mandatory retirement of individuals based solely on attainment of a specified age below seventy to be void. In 1987, all age limitations were abolished. ${ }^{57}$

The August 1982 United Nations World Assembly in Vienna was devoted to questions of the elderly. As a result of this conference, specific measures were suggested. ${ }^{58} \mathrm{~A}$ warning was issued against short-term solutions to problems such as attempting to reduce unemployment among younger members of the population by measures which might create a longterm problem. ${ }^{59}$ This long-term problem was seen by the UNO World Assembly in the reduction of the retirement age! Furthermore, numerous suggestions were discussed, including supporting self-employment as well as conventional employment among the elderly. ${ }^{60}$

In the Federal Republic, experts have also issued a warning against abruptly severing older persons (and younger persons as well) from an important part of their life, their work. This issue has been very convincingly debated. It is true that sheer muscle strength for persons over fifty sinks to approximately 70 percent of its previous level. ${ }^{61}$ The counterpoint to this argument, however, is that even in jobs involving pure physical labour, physical demands do not exceed this reduced capacity. Of even greater significance, however, is the argument that in the face of increasing automation and mechanization, physical labour loses substantial meaning.

The actual performance level of more or less intellectual labour depends primarily on other factors. Education and mental exercise have a significant effect on mental ability and are able to combat the mental weariness which undeniably occurs with age. ${ }^{62}$ This validates an old saying: "If you don't use it, you lose it". Lehr ${ }^{63}$ altered an old saying slightly to read; "That which rests, rusts".

56 Ibid.

${ }^{57}$ Cf. Lehr (1988), p. 10.

58 United Nations World Assembly on Aging, International Plan on Action on Aging, Vienna, 1982; cited in Oriol (1984), p. 19, which also contains other references to UNO publications.

${ }^{54}$ Cf. Oriol (1984), p. 17.

${ }^{60}$ Cf. also Lehr (1987a), p. 124.

${ }^{61}$ Lehr (1988), p. 10; next to last column.

${ }^{62}$ Lehr $(1987 \mathrm{~b})$, p. 184; here is also a reference to the change from the industrial revolution to the "information revolution" and the subsequent increasing meaning of "brain work" associated with this change; Müller (DRV 1987), p. $30 \mathrm{ff}$. (38) also cites the shortening of the work-week as a factor having a positive influence.

${ }^{63}$ Lehr (1988), p. 10, Column 2. 
In the light of all this, from a gerontological perspective there are no fundamental obstacles to the employment of the elderly. Deficiencies and problems arise more frequently from other considerations.

More than ever before, a situation must be created in which knowledge and capabilities need not atrophy. Older persons must be able to assume other tasks in a timely manner which are more suitable to their particular situation and age. With this, an issue is addressed which recently appeared in the press under the headline. "Once Again at University - at Age 60". ${ }^{64}$

What is at stake here is a whole range of measures for retraining, reeducating and rehabilitating persons who are now working, as well as those who would like to return to their jobs - which are today, unfortunately, predominantly women and the unemployed. The opportunity for further education has, of course, a special meaning for workers in fields where new and increasingly sophisticated technology is continually introduced. ${ }^{65}$

One measure of geroprophylaxis, in the broadest sense of the word, is the stimulation of awareness, primarily among employers and colleagues of elderly employees, that the mere attainment of a certain age does not imply the emergence of physical or mental handicaps. ${ }^{66}$ This is all the more valid as, in the opinion of younger persons and depending on the professional field, work colleagues between the ages of 35 and 40 already belong to the group of persons "handicapped" by the onset of old age. ${ }^{67}$

In closing, it must be remembered that the above tasks are long-term endeavours. In this respect agreement exists with the UNO World Assembly. The challenge of an aging society - not just under the pressure of the present discussion of retirement policies - is to prevent persons from going through a phase, which may last approximately one-quarter of their lives, in which they are seen as "useless" or "superfluous". The feeling of not being needed can also have an effect on an individual's health which can have further detrimental and unforeseeable effects on other branches of the social system. Therefore, not only are there no reasons to hinder the employment of elderly persons from a gerontological perspective, their employment is, on the contrary, strongly desired.

\section{iii. Business approach}

New challenges arise for the economy as a result of these expected changes. More flexibility will be demanded not only of employees, but also of establishment and enterprises. One must reckon with a long process of rethinking and restructuring. This expected development should therefore be anticipated, and given careful consideration at an early stage.

The past trend - even for top-level executives - of severing the formal working relationship with elderly employees because they are allegedly no longer able to perform at an

64 Cf. Mohr (1988), p. 12.

$65 \mathrm{Cf}$. on this point Stooss, in the most recent edition of "Mitteilungen aus der Arbeitsmarkt- und Berufsforschung"; cited in $F A Z$ (May 14, 1988), p. 39.

${ }^{66} \mathrm{Cf}$. on this issue and for deficiency models found in psychological literature, Lehr (1987b), p. 184, and Lehr (1988), p. 10, Column 4.

${ }^{67}$ Lehr makes numerous references to this special form of relativity of personal opinions; Cf. Lehr (1987b), p. 181 and Lehr (1988), p. 10, Column 4. 
acceptable level, they are not mobile and last but not least, too expensive, begs the question as to whether a reversal of this process is even possible. This question will be answered, on the one hand, by the labour market. If younger persons cannot be found for important positions, older persons must remain employed. One must convince these older persons to continue working. On the other hand, this continued working relationship can and must receive support on a socio-political level similar to that given to premature retirement through present government regulations.

The task for the company remains that of utilizing older persons who are not in general poorer workers, but rather have "other" talents. What is at stake here is a "cost-benefit" analysis. The negative factors of advanced age must be weighed against the positive advantages of older workers. These negative factors include somewhat slower reaction times, longer recuperation periods, and increasingly shorter periods of high performance. The positive factors of these workers, however, are "company discipline", willingness and ability to bear responsibility, years of experience, and last but not least, the capacity to balance personal interests and professional duties.

Additional, greater problems as well as costs result, however, for the management of the company. This change will have an effect on management style. Experienced, but somewhat stubborn elderly workers, place higher demands on the right to join management in leading and directing corporate policy. On the other hand, these demands represent the newest trend, and need only to be further developed.

In closing, another practical problem must be noted. Increasing the retirement age will require companies with old-age provisions to alter their respective programmes to take this development into consideration. It is, however, not necessary in the context of this study to discuss other related problems.

\subsubsection{Prolonging lifetime employment as a result of the self-regulatory mechanism of the labour market?}

Since the previous sections have been concerned with ascertaining that there are no basic obstacles to the employment of the elderly, this section is devoted to the question of how this may be implemented in practice. In this context, the first question which arises is: What effects can be expected from the spontaneous behaviour of elderly employees?

In the VDR Report ${ }^{68}$ it is considered "highly probable" that insured workers would increase their length of labour market participation on their own. In addition to the prerequisite for improved economic conditions - above all, corresponding labour market demand for elderly workers - the VDR Commission also mentioned that the financial incentives for continuing employment must be sufficiently large. This aspect will be explored further, but first another problem must be addressed.

Also expressed in this VDR Report is the opinion that the present regulation of the "additional earnings boundary" 69 which facilitates a "free rider" effect, poses an obstacle to self-regulation. Here precautions must be taken so that early retirement pensions

68 VDR Report, p. 174; Cf. also Doetsch (DRV 1987), p. 518.

${ }^{69}$ Müller (DRV 1987), p. 30 ff. (38) holds this upper boundary for unnecessary on the assumptions mentioned in his work. 
accompanied by not necessarily low additional earnings, will not appear too lucrative. These remarks make it clear that a new legislation cannot be avoided, even though the VDR Commission considers that this could be superfluous with respect to an increase in the retirement age.

But there are also other reasons to be sceptical about the self-regulatory mechanism of the labour market. Once it is assumed that activity will not be legislated, then premature retirement would increase the profitability of employee-employer pension plan contributions, as acturial reductions are not proscribed for the receipt of flexible pensions. ${ }^{70}$

Furthermore, an employee's decision as to when to enter retirement depends on his or her individual financial situation. According to a study conducted by the Ifo Institute at the end of 1987,71 the percentage of workers with company old age benefit plans was 72 percent for industrial workers and 28 percent for those in commerce. In addition, a large number of employees in the public sector must be included, who are insured under additional social insurance provisions. Finally, the significance of increasingly effective private provision schemes should not be underestimated.

By combining one or more of the sources of income mentioned above with a pension provided by the Federal Old Age Retirement Plan (the net pension level after approximately forty years of coverage being approximately 63 percent), it is possible for a significant proportion of retirees to earn incomes of between 80 and 90 percent of their last (net) pay level. It is obvious that here a forward-looking policy cannot afford to rely on self-regulation through the labour market to such an extent that the strain of financing old age pensions could be somewhat alleviated. All the more so as in future reform discussions, whose focal point will certainly be an increase in payroll contributions, it is advisable not to require older employees to pay these increased contributions out of the earnings from their prolonged work.

The preceding considerations lead to the conclusion that upon realization of the goal of a lengthened period of employment, even under favourable economic conditions - which are required in any case - self-regulation via the labour market cannot be relied upon. Legislation must intervene. Of course, the possibility that additional desirable effects can result from self-regulation cannot be excluded.

\subsubsection{Legislative increase in the retirement age}

In this section the question of whether possible legislative alternatives exist for influencing the length of employment is discussed. Lengthening the years of labour market participation and thereby lessening the financial burden by decreasing the length of retirement is the focal point of the following discussion. This reflection must consider the conditions of the Federal Old Age Retirement Plan, namely, that the German system recognizes not just one level of pensions with an associated age restriction, but a large number of pension provisions and disability insurances, each with respective requirements for guaranteed benefits. One must consider this aspect in further discussions when examining the legality of increasing the retirement age or the possibility of eliminating specific types of old age provisions.

70 The motivating effects of bonuses and reductions are clearly enumerated in Müller (DRV 1987), p. 30 ff. (38).

${ }^{71}$ Cf. Ifo-Institute (1988), p. 1. 
This will be the methodology employed in this section. In connection with this, the expected financial consequences for the old age pension plan, on the one hand, and insured workers on the other, will be roughly sketched.

\section{a. Increasing the retirement age and its legality}

This question refers to the legality of the issue at hand. As such, this question is independent of the type of pension; it still must be considered in each individual case.

\section{i. Comments on general requirements for acceptability}

The element of longevity is inherent in old age insurance, both from the perspective of the "man on the street" and for the institution of Federal Old Age Retirement Insurance. Long-term precautions are required in order to guarantee a desirable, or at least socially acceptable, standard of living in old age. In a "pay-as-you-go" system, however, former employees entering retirement are dependent on the payroll contributions of those still working in order to redeem their "promised" benefits.

Workers who are still active must trust that the "generation contract" will still be in force when they become eligible for benefits. Because of this they specify concrete expectations as to the benefits from the system. With respect to old age pensions, this means that current long-term plans can, for example, be built on the expectation that, ceteris paribus, one can begin to receive early retirement pension benefits at age 63 without being subject to any actuarial reduction. All private pensions provisions made above and beyond this, which consider the total benefits level one could obtain in connection with employee benefit plans upon attainment of a certain age, for example, are contingent on reliable "data" regarding the Federal Old Age Retirement Plan.

From a legal perspective, the above considerations can be summarized in the Principle of Limited Retroactivity, which is based on the concept of constitutional legality. This principle has ben reinforced in numerous precise decisions stemming from the Federal Constitutional Court regarding the protection of property. Consequently, it is important that precisely the claims awarded through the Federal Old Age Retirement Plan - expressed in legal jargon as "Equivalent Benefits" 72 - are based only to a small extent on governmental guarantee. According to the opinion of the Federal Constitutional Court, this also constitutes grounds for intervention in protection of property. According to its legislative precedents, there are three possible distinguishable groups of persons affected.

The first group consists of those who do not yet receive insurance benefits. For this group, an increased length of covered time is not problematic from either a trust or protection of property perspective..$^{73}$

The second group consists of insured persons, who have not yet fulfilled all the requirements for receiving full social insurance benefits. In the decision cited above, the Federal Constitutional Court, (Bundesverfassungsgericht, or BVerfG) expressly stated how these persons are to be treated. Here, the Protection of Confidence concept is to be given more weight than the Property Protection concept. In this context, the BVerfG has always

72 On this criterion cf. Decisions of the BVerfG (BVerfGE) 14, 288 ff. (294); 18, 392 ff. (397); 24, 220 ff. (225 ff.); 48, 403 ff. (412 ff.); 53, 257 ff. (291 ff.); 69, 272 ff. (300).

${ }^{73}$ For claims to unemployment provisions cf. BVerfGE 72, 9 ff. (22). 
emphasized that the legislative body (especially in the area of Federal OId Age Retirement Plan ${ }^{74}$ ) must, for the general welfare, also be in a position to lay down new rules which are commensurate with changing requirements. One does not need to be able to foretell the future to recognize that the BVerfG considers financial guarantees to insure the fundamental security of the Federal Retirement Plan with respect to benefit levels as a contribution to the general welfare. It has expressly named the resilience of the risk-pooling provisions as one of the criteria to be considered..$^{75}$ With respect to increasing the retirement age, there exists among this group further room for manœuvre.

This margin for action is the smallest in the third group. This group consists of active workers, ${ }^{76}$ who have actually already fulfilled the requirements for a certain level of retirement benefits and who are still in the preretirement waiting period before their claim to full benefits can be secured. ${ }^{77}$ Here, a breach of property rights can occur if the intervening legal norms fulfil all requirements of Article 14 of the Basic Law with respect to their consequences for the future. This is because the issue at hand is the question of guaranteed legal claims made in the past. Therefore, in order to intervene in the case of a change in effective law, the legislative body must have legitimate reasons. Here the principle of equity must be especially considered, as increased retirement age must be possible in order to bear the costs of demographic developments, and particularly, increasing life expectancies. Furthermore, it is significant that lengthening the time of expectancy represents a complete devaluation of the legal position of the insured. It is demanded by the principle of equity that transition periods be provided such that even the third group of affected persons is able to adjust to the new situation and make their future financial plans accordingly. This result is not so difficult when considering the goal of increasing the retirement age. However, the situation in the labour market will only make its full realization possible after the year 2000 ; therefore, the need for short or medium-term action does not exist. ${ }^{78}$

For all groups it can be said that in future appropriate legal measures must be undertaken, even if they actually take effect at some later point. In addition, they must be able to be implemented without fundamental misgivings regarding their constitutionality.

ii. Possible amendments and suggestions for change for individual existing old-age retirement plans

aa. Current allocation of and prerequisites for old age pensions

As a starting point for further considerations, it is necessary to establish that the de jure mandatory retirement age in the Federal Republic is 65 years. The normal old age pension, which is payable upon attainment of this age, is available to all insured persons who can prove that they have 60 months of covered work. Until the 1984 enactment of the Haushaltbegleitgesetzes (law accompanying the budget) the necessary minimum number of months

${ }^{74} \mathrm{Cf}$. above all BVerfG 69, $272 \mathrm{ff}$. (309 ff.).

${ }^{75}$ BVerfGE 69, 272 ff. (309) below.

76 Those persons who already receive retirement benefits could, of course, no longer be affected by a lengthening of the period of expectancy.

77 BVerfGE 53, 257 ff. (289 ff.); also cited in BVerfGE 69, 272 ff. (289). tations

${ }^{78}$ In this context, cf. also Müller (DRV 1987), p. 37, for detailed statistics on labour market expec- 
was 180 . When comparing conditions in 1984 and 1986, the changes associated with this law can also be seen as a reason for increasing claims made to normal old age pensions, especially by females. ${ }^{79}$ Among insured persons who filed no disability insurance claims, the actual retirement age for one-third of the males and over half of the females was exactly that set forth in $\S 1248$, Section \& RVO / $\$ 25$, Section 5 AVG.

Nevertheless, the percentage of males as well as females filing pension claims for early retirement is considerable. For males, most important is the early retirement pension according to $\S 1248$, Section 1, 1st Alt. RVO and $\S 25$, Section 1, 1st Alt, AVG. The precondition is a minimum requirement of age 64 and 35 valid years of covered employment (with an insurance time of at least 180 calendar months). This alternative was used by just under 28 percent of the males who became eligible for retirement in 1986. If a physically handicapped person or a person declared incapable of working meets these requirements, he or she is eligible for an old age pension (not included in the disability pension) at age 61 . The corresponding share of these persons receiving old age pensions and meeting these requirements was approximately 22 percent. Finally, the percentage of males receiving socalled "Unemployment Old Age Pensions" was 18.5 percent ${ }^{80}$

For females receiving no disability insurance (according to a decree report of the Haushaltsbegleichungsgesetz), this was approximately 80 percent of females in $1984,{ }^{81}$ other than the normal old age pension, after age 60 only the so-called "Females' Old Age Pension" plays a significant role. In 1986, 42 percent of females began receiving benefits from this pension. As all other pension forms showed a maximum of 1.5 percent participation, they will not be considered further in this analysis.

\section{ab. Suggestions for increasing the retirement age in individual old age pensions}

For reasons of topical relevance, and not because of any special priority, this discussion begins with the question of the Female Old Age Pension. Only as late as last year has the $\mathrm{BVerfG}^{82}$ begun to study the equity principles of the corresponding pension law provisions. Once again, the discussion revolves around the question of whether or not differing retirement ages for males and females, as foreseen in $\S 1248$, Section $3 \mathrm{RVO} / \S 25$ Section 3 AVG, under equal conditions (such as child-rearing), are not contradictory and unconstitutional with respect to the equality principles and, therefore, invalid. In 1987 the BVerfG answered this question in the negative. The reason is pertinent for this study, as this could render the question of a separate retirement age for females superfluous under certain demographic conditions.

The justification for this discrepancy, simply stated, lies in the double burden for females having both families and professions. With reference to the $\mathrm{BfA}$, the BVerfG

${ }^{79}$ Males: $1984-23.4 \%, 1986-31.7 \%$; females: $1984-36.4 \%, 1986-53.4 \%$; statistics taken from Schüle (1988), p. 11, Table 1. They are based on percentages of old age retirement funds, and do not include disability pensions.

${ }^{80}$ These provisions, made more stringent in 1982, are regulated in Par. 1248, Section 2 RVO / Par. 25, Section 2 AVG.

${ }^{81}$ By contrast, over 40 percent of males became recipients of disability insurance in 1986, implying that only 60 percent of all males received only old age pensions; cf. Schüle (1988), p. 14, Table 2; Conradi, Jacobs and Schmähl in Sozialer Fortschritt (1987), p. 184, Table 2.

${ }^{82}$ BVerfG Decision of January 28, 1987, NJW 1987, p. 1541 ff. 
alluded to the previously recorded educational deficits of females and the consequences of this for their professions, especially their pay. Finally, according to the opinion of the court, female-specific interruptions of life employment justify privileged treatment of women, because they generally have no chance to fulfil the requirements of early pension plans. Until the beginning of 1987 , the BVerfG did not recognize any fundamental changes in this disadvantaged situation of females. ${ }^{83}$

The assessment of recent developments in the Federal Welfare Court is, however, of interest. ${ }^{84}$ The court holds a time span of only ten years for not easy to assess. This means that the court itself considers a drastic change in male and female roles in such a short time possible, so that the elimination of the Female Old Age Pension could only be considered constitutional. In order to be able to reach this conclusion, it is necessary to conduct more precise studies so as to make possible such a difficult decision. If this special pension fund could be eliminated without introducing new problems for women, ${ }^{85}$ then substantial burdens on the system could be reduced.

It is, however, questionable whether intermediate- and short-term solutions would be legally valid in the meantime. In addition, the reasons mentioned above for introducing the Female Old Age Pension must also be considered. ${ }^{86}$ They actually move its origin and function in the direction of a disability pension (based on wear and tear). Therefore, a slight increase in the retirement age could be justified. With a ruling which would first affect currently forty-years-old females, one could come to the conclusion that, with the growing availability of new technical household appliances, and considering that planned changes need not be restricted to legislation affecting only men, an increase in the retirement age to 61 and then in five or ten years to 62 or 63 would certainly be justified. Furthermore, legislators could eliminate the Female Old Age Pension under protection of the transition period named above. Strong political criticism would certainly have to be reckoned with and in this case, the problem of equal rights for men and women would have a special constitutional aspect to be discussed. These problems would occur as long as no fundamental changes take place in male-female roles.

A further consideration, especially for the male population, is the so-called "flexible retirement age", to be eliminated over a two-stage transition period. Under this plan, one could increase the retirement age first to 64 years (between the years 2000 and 2010) and, five to ten years after that, completely eliminate this particular old age pension form. In order to achieve this, the following must be considered:

83 This pattern of argument is employed by the Federal Labour Court and by the Federal Welfare Court; Cf. BAG BB 1979, 477 and BSGE 53, 107 ff. $(109,111)$, respectively.

84 BSG, Decision of September 9, 1982, SozR 2000 (2200), Par. 1248 RVO, No. 37.

${ }^{85}$ Due to the limited requirements for a complete elimination of the Female Old Age Pension presented here as well as further suggestions, no further consideration is necessary as to how it is possible for females to enter premature retirement. Cf. GVG, Arbeit und Sozialpolitik (1987), p. 110, for further discussion.

${ }^{86}$ For a history of its origins of BT-Drucksache II/3080, p. 10; Brackmann, p. $684 \mathrm{~m} / 685$; the BVerfG first addressed the issue of Female Old Age Pensions in 1963; cf. BVerfG Decision of July 24, 1963, NJW 1963, p. 1723. 
Persons would be included, who, on average, entered the work force ten years later than those persons who are now reaching retirement age. The latter have just acquired the opportunity to use their time out of the workforce with associated financial advantages. They belong to the generation that has vivid memories of the war and post-war period.

For these reasons, the introduction of the premature retirement pensions in 1973 appeared as certainly justified. As just shown, equally valid reasons exist for its elimination in the year 2000. It is not even necessary to examine whether the post-war generations who grew up in affluence on the average have the chance to spend longer years after 65 in good health. ${ }^{87}$

Finally, the proposal presented here should not be considered separately from proposals for a flexible transition into retirement, but should rather be considered in this context and in connection with the introduction of partial pension plans. It is through these that the consequences of the elimination of the premature retirement pension can at least be mitigated.

The Unemployment Od Age Pension and the Flexible Old Age Pension (on the basis of health considerations) will be addressed in the following section by considering supporting measures.

Conclusion: In those forms of the flexible old age pensions which are relevant in terms of volume (valid beginning at age 64 ) and the female old age pensions, the retirement age should first be raised by one full year. The former should be completely eliminated by the year 2015. The elimination of the latter can only be advocated together with a fundamental change in the situation of women in the family and in professional life. In any case, a one-year increase in the retirement age is necessary until the year 2000, and until 2010, a further increase of one to two years is expedient. Nonetheless, a uniform retirement age of 65 for men and women is the goal which should be pursued.

The proposals we make here take into consideration a very cautious assessment of the constitutional criteria in existence. This does not rule out, however, that other laws discussed in the context of a reform of the structure of the old age pension system in the Federal Republic of Germany, ${ }^{88}$ could also be constitutionally sound.

\section{ac. Supporting measures}

In a procedure of this sort, the most important goal for measuring the effectiveness of the measures to be employed is the prevention of misuse of disability pensions. Due to the concretely expressed opinion of the Federal Welfare Court, ${ }^{89}$ the creation of a well-functioning labour market capable of supporting part-time employment takes on substantial meaning, even insofar as restrictions on disability insurance claims are concerned. Alternatives could exist in two special old age pensions, i.e. the old age pensions for the unemployed and the severely handicapped. Both old age pension plans should be eliminated in the light of the following considerations.

${ }^{87} \mathrm{Cf}$. for a discussion of this aspect and the necessity for renewed consideration of the third phase of life Tegtmeier, in GVG (1988), p. 6 ff.; also cf. Lehr (1987b), p. 188.

88 Cf. Report in FAZ (July 19, 1988) p. 1

${ }^{89}$ Cf. Erlenkämper (1984), p. 371 with sentence indications. An explanatory overview is also provided by Lehr (1987b), p. 188. 
When one assumes that an increase in the retirement age is mcaningful only after a fundamental change in the labour market has occurred, one can then expect only limited alleviation of financial problems for the old age insurance via an increase in the retirement age requirements of the Unemployed Old Age Pension. Nevertheless, prccisely at that point, one should consider eliminating old age pensions for the unemployed to streamline the system. This would mean that unemployment insurance would have to be resorted to in the remaining cases of unemployment.

This "streamlining" argument is also employed as the reason for eliminating pensions for the severely handicapped. ${ }^{90}$ This means that this sort of old age pension would be replaced through disability pensions or unemployment cheques. The following must then be considered: legislators have not just unintentionally regulated jointly this old age pension and the flexible old age pension beginning with age 64 (discusscd above) in the same section of $\S 1248 \mathrm{RVO} / \S 25 \mathrm{AVG}$. For both, specific reasons were present which suggested that a rigid retirement age was not justifiable on the basis of differing abilities of elderly insureds. Under these conditions, the partial pension model must bc considered. Furthermore, by fulfilling necessary conditions, it is possible to receive a disability pension. The elimination of old age pensions on the basis of declining health can, therefore, be justified.

\section{b. Magnitude of the gains from increasing the retirement age}

It is not possible to present original model calculations here. In addition, very few studies exist in the literature which address this issue in greater detail.

The Federal Minister for Labour and Social Organization (Bundesminister für Arbeit und Sozialordnung) has conducted a study under the auspices of the Social Policy Commission (Sozialbeirat) ${ }^{91}$ in which all pensions, including the EU/BU-disability pensions, were represented as being obtainable one year later than provided under present law. It was clearly shown that this assumption could not be equated with a one-year increase in the retirement age .92 The formulation, however, leads to misunderstandings as it is not clear whether the regular retirement age is meant. Because of the warning against seeking alternatives (in the form of other pension funds) which then follows, this interpretation seems to be confirmed. According to the results of this calculation, a partial alleviation of the financial burden is expected for the year 2005 which amounts to approximately 1.5 percentage points of the payroll contribution.

Another model was produced by Müller in 1987 for the Verband Deutscher Rentenversicherungsträger for estimating the potential for reducing the financial burden. ${ }^{93}$ In this model a method was pursued which was designed to explain the larger effects. The

${ }^{90}$ Cf. the proposals of the "Old Age Retirement Insurance Structural Reform", Committee of the Association for Insurance Studies and Insurance Structure in Arbeit und Sozialprodukt (1987), p. 107 ff. (111), where a complete elimination of the old age retirement pension on the basis of health limitations is considered.

91 Cf. Sozialbeirat (1986), p. 20 and Diagrams 6 and 7 on pp. 21 and 22.

92 Only a half-so-high alleviatory effect, with respect to the assumptions of the Sozialbeirat, can be expected here; cf. Ibid., p. 21, Footnote 3.

${ }^{93}$ Müller (DVB 1987), p. 38 ff; a summarized presentation of Müller's results can be found at the end of the GVG proposal in Arbeit und Sozialpolitik (1987), p. $113 \mathrm{ff}$; cf. also Clausing in GVG (1988) p. $37 \mathrm{ff}$. 
starting point of this model was an increase in the minimum retirement age from 63 to $65,{ }^{94}$ beginning in the year 2000. Müller then assumed that 25 percent of the persons presently under this level "defect" to disability pensions. ${ }^{95}$ The frequency with which this is actually observed among 50 to 60 -year-olds was equivalent to values known in the sixties. Because of further assumptions, and especially because of the fundamental economic scenario, it is advised to refer to Müller's detailed explanations directly. Within the low-range scenarios of economic development, Müller, using a minimum retirement age of 63 , obtained a reduction in the payroll contribution rate of approximately 1.4 percentage points in 2015 to just under 2 percentage points in 2025 , ceteris paribus. The corresponding values for a minimum retirement age of 65 were 2.4 percent for 2015 and 3 percent for $2025 .{ }^{96}$

What significance does this model have for the proposals presented here? By eliminating the Unemployment Old Age Pension Fund, the pension for the severely handicapped, and the Premature Old Age Retirement Provision by the year 2010, and by increasing the retirement age for females to 62 or 63 in this time frame, a reduction in the systematic strains could be realized which, as estimated by Müller and assuming a minimum retirement age of 63 , could mean between 1.4 and 2 percentage points on the payroll contribution rate.

A correct estimate of the proposals suggested here, as previously mentioned, is obtained through a combination of factors, which include flexible transitions to retirement. It is then possible that an additional positive effect may be felt, as will be discussed in the next section.

\subsection{Flexible transition into retirement as an additional way to prolong lifetime employment}

Until now, only an increase in the retirement age and the elimination of certain pension forms have been discussed. That alone would do little to change the long considered regrettable situation that employees at the end of their working life perform at a full workload on one day and then the very next day have nothing to do. Here specific proposals have been offered which are in the interest of elderly employees and are aimed at creating a gradual transition into retirement. It is, therefore, all the more justified that these suggestions be considered as a way to lengthen the working life of an employee.

\subsubsection{Flexible transition into retirement: concept, form and opportunities}

Before the structure of these suggestions can be explored, the concept of "flexible transition" will be explained in order to develop a fundamental understanding of the issue at hand.

\subsubsection{The concept of "Flexible Transition"}

The term "flexible transition" encompasses a number of diverse concepts.

a) It is possible that nothing more is meant than the possibility, which already exists today, of completely stopping all substantial activity at a definite point in time, designated

94 The EU/BU pensions are still allowed under this level.

95 Müller (DRV 1987), p. 39.

${ }^{96}$ For further discussion of these values and on the reduction of the minimum retirement age and volume of the pension, cf. Müller (DRV 1987), p. 43. 
as the retirement age. Here the possibilities of receiving "premature" retirement pensions benefits ${ }^{97}$ must be mentioned. This is effective for males as of age 63 and for females as of age 60 . This represents a concept of "flexible transition".

b) The laws presently in effect also allow for an increase in the age limit of insureds. According to $\S 1248$, Section $6 \mathrm{RVO} / \S 25$, Section 6 AVG, the insured can determine that a later time than that corresponding to the completion of his 65 th year be the effective time of entrance into retirement. In this case employee benefits will be further increased according to $\S 1254$, Section 1 , Line $1 \mathrm{RVO} / \S 31 \mathrm{AVG}$, if the employee has met all the requirements for receiving old age pension benefits, but does not lay claims to these until he is at least 68 years old. ${ }^{98}$ This alternative obtains significance when the insured has not yet fulfilled the waiting requirements or when the insured wishes that absentee periods be included through the payment for further obligatory contributions. ${ }^{99}$

c) Flexibility in the sense of a "flexible" retirement age proves itself to be rigid as the entrance into retirement, with respect to retirement benefits, can only proceed "comprehensively". ${ }^{100}$ If the requirements for the relevant old age pensions are met, the right to full retirement benefits exists. Nothing changes if the insured is employed or self-employed at the same time. ${ }^{101}$ In contrast to this, an actuarially correct provision (with respect to old age pension norms) which foresees supplementing pensions and salaries into a single income, does not exist. Here is where the suggested "partial pension" model has recently appeared. ${ }^{102}$ At stake here are proposals for a combination of part-time wages with a portion of the pension accruing from the Federal Old Age Retirement Plan, i.e. it is a pensioninsurance based solution, and thereby compatible with the social legislation.

The flexible structure of the transition period into retirement thus takes a different image. The changeover from working life, whether legally regulated or collectively bargained, does not occur at a fixed point in time. Rather, it is a process which proceeds over a number of months or years. Through this, the burden associated with former labour force participation is reduced, especially in time. One aspect which must be considered in discussion of a "flexible transition into retirement" is that elderly employees, during a temporary phase, work only part-time. ${ }^{103}$ What is meant here is a shortening of the time worked relative to the usual duration as mandated in company contracts and/or collective bargaining agreements and legal regulations. ${ }^{104}$ This concept is the basis for the following discussion.

97 The exact legal distinction between "flexible" and "premature" old age pensions does not need to be enumerated here and will be excluded so as to avoid semantic confusion; for details cf. Bley (1986), C III 3 d, bb-dd, p. 227 ff.

98 Further details, in particular the regulations, calculation, and amount of this supplement, will not be discussed here; cf. Erlenkämper (1984), p. 378, for further references to individual problems.

99 In 1986, the percentage of males/females beginning to receive retirement pensions was 0.3 and 0.2 percent respectively; cf. Schüle (1988), p. 11.

100 Franke formulated this as an "all or nothing" rule; cf. Franke in GVG (1988), p. 27.

${ }^{101}$ However, in the cases of "premature" pensions, a maximum earnings level exists, according to Par. 1248, Section 4 RVO / Par. 25 AVG. $2297 \mathrm{ff}$.

102 It is based on a suggestion by the Board of the BfA; cf. DRV 1987, and Glombik bb 1987, p.

103 For more information on this phase, cf. Stitzel in Schmähl (1988), p. 225 ff.

104 Cf. v. Maydell in Schmähi (1988), p. 195. 


\subsubsection{Forms of "Flexible Transition"}

In practice such a flexible transition is found only in rare, individual cases in the Federal Republic. By contrast, six other European countries have decided to introduce models of flexible transition throughout their territories and on a legal basis. ${ }^{105}$ However, as these models have a function similar to the German Retirement Law and have primarily an employment-policy character, they will not be considered in further detail.

\section{a. Flexible transition under existing labour legislation}

In the Federal Republic of Germany, only forms having a labour-law character have been put into practice. They contain provisions for one or more phases to reduce working time to a twenty-hour work week. Juxtaposed to this are models which provide for increased "leisure" in the form of substantially longer paid vacations, beginning in a specified agebracket. ${ }^{106}$

The form just mentioned is characterized as having a labour-law character, first, because it is exclusively applied through collectively bargained wage contracts and company agreements, and second (but more important), because the question of financing is regulated exclusively between the affected parties. Two points must be mentioned here: the high amount of older-age employee pensions and the fact that financial losses consequent to part-time work must be borne by the employer. On these grounds, it is certainly no surprise that it is almost exclusively large enterprises - and very few, at that - which are able to offer employees this option.

The greatest amount of public interest has been directed to the wage agreement in the cigarette industry ${ }^{107}$ and the chemical industry, ${ }^{108}$ as well as to Siemens' company agreements. ${ }^{109}$ Other company agreements include those of Daimler-Benz AG, Pegulan, and Weingut Pieroth. 110

Within this study it can only be mentioned that problems can result from the implementation of such flexibility transition models. ${ }^{111}$ Such problems must likewise be considered if the legislator approves a solution that is compatible with social legislation - and, therefore, compatible with pensions insurance legislation - and which contains provisions for part-time employment positions for elderly employees.

105 Sweden (since 1976), Great Britain and France, Spain (since 1984), and Denmark and Finland (since 1987); cf. overview by Schüle (1988), p. 37; for specific information on the Swedish model, cf. Clausing in Schmähl (1988), p. 181; Kreikebohm (1986), p. 227 ff.

106 For details of this plan, cf. overview by v. Maydel in Schmähl (1988), p. 195-197.

107 General agreement concerning minimum pay scales for employees in the cigarette industry of July 3, 1981 (effect beginning July 1, 1981).

108 General minimum pay scale agreements for blue and white collar workers in the chemical industry in the version of March 25, 1983 (IG Chemie), as well as the collective agreement on preretirement and old age part-time employment of March 1, 1985 (DAG) and the collective agreement on part-time employment of April 13, 1987 (IG Chemie), the latter found in NZA 1987, p. $482 \mathrm{ff}$.

109 This model is firmly presented by Schusser in Schmähl (1988), p. $213 \mathrm{ff}$.

110 Cf. v. Maydell in Schmähl (1988), p. 194.

111 For more on this point, cf. v. Maydell in Schmähl (1988), p. $204 \mathrm{ff}$; in particular, on the problems of the realization of these model types, especially in consideration of company old age pensions, cf. p. $206 \mathrm{ff}$. 
In general, the opinion may be ventured that existing models, as mentioned above, which provide for a sliding retirement phase, should be able to be integrated into a partial pension model whatever the individual details.

\section{b. A social and legal solution: partial pensions}

The Federal Insurance Agency for Salaried Employees (Bundesanstalt für Angestellte, or $\mathrm{BfA}$ ) has introduced a partial pension model the basic features of which will be represented here as a starting point for the analysis of models of this type. ${ }^{112}$ As in all partial pension models, a crucial assumption is that the loss of income associated with limited or curtailed labour force activity by employees towards the end of their lives requires some compensation for those concerned to accept a sliding transition into retirement. This compensation can guarantee the payment of a partial pension.

According to the BfA Model, these claims can first be made beginning with age 60 , assuming a de jure retirement age of 63 . This reckons with supplements or reductions in benefits before or after age 64 which are not applicable to those who would have been eligible for benefits under present law before age 63. For insured persons who would have been eligible for benefits as of age 64 , but who had to relinquish their part-time employment before this time for reasons of disability, a compensation for threatening, long-term reductions of social insurance benefits should be offered. Finally, the BfA Model recommends that the part-time employment phase be ended at age 66 .

In many respects, a critical examination of this model is necessary. Taking into consideration the proposals presented here, and to avoid a not particularly desirable legislative determination of the legal retirement age at 63 years, the orientation point of a partial pension model should be age 66 . If any other age is used, this model is incompatible with the goal of lengthening the number of years in the labour force.

The sliding phase which is sought should begin before this time, which makes the BfA proposal of a three-year time frame feasible. This phase could begin with age 63. To avoid imposing additional financial burdens on the Federal Old Age Retirement Plan, actuarial compensations are deemed necessary. According to calculations made using the BfA Model, ${ }^{113}$ these actuarial compensations could be in the order of 5 percent of the yearly pension amount of the early partial-pension benefits before age 66 (this figure is, however, probably slightly higher than what will actually occur).

Appropriate compensation should be made for part-time employment continuing beyond the age limit proposed here. With this compensation, a reduction in the welfare level which would occur under partial pensions could be brought under control. It is not clear, however, why the part-time employment phase should be ended so soon after attainment of the legal retirement age (in the BfA Model, with age 65, here, with age 67). This must be extended by two or three years. The fact that part-time employment over the retirement age is a free choice could well support this suggestion.

${ }^{112}$ A well-summarized and especially clear overview can be found in Bäcker/Steffen (1988), p. 173; this presentation serves as the reference for further model details. A similar presentation is found in Schüle (1988), p. 45. p. $44 \mathrm{ff}$.

${ }^{113}$ Cf. Clausing in GVG (1988), p. 42; on problems of actuarial compensations, cf. Schüle (1988), 
With a complete realization of the concepts presented here, the question would not arise of how insured persons who demand old age pensions before the legal retirement age of 65 are to be treated. This is different from the BfA model.

The same applies to the definition of eligible persons. Here problems could occur only if the partial pension were introduced and the specific Female Old Age Pensions contained a transitional retirement age of 61 . In this not improbable case, the partial pension should be made available without reductions to women who have fulfilled the requirements for receiving benefits from the Female Old Age Pension.

Two factors play a role in determining the amount of the partial pension. First, the length of covered employment until entrance into partial employment, and second, the extent to which employment is curtailed. The actual loss of income is not considered in order to be able to integrate the partial pension model into the present social insurance system. ${ }^{114}$

Both the BfA Model and the concepts discussed here face fundamental problems which must be addressed at this point.

First, a substantial extension of the part-time labour market model through attractive opportunities, in particular for elderly persons, is necessary. Thoughts must, therefore, be directed towards developing incentives, especially in small enterprises.

Because a partial pension model is directed towards a combination of pension benefits and salaries, obstacles arising from too low maximum allowable earnings levels must be eliminated. It should be checked whether a maximum level of allowable earnings could be eliminated for the partial pension plans. ${ }^{115}$

In considering this aspect and the modification of the BfA Model presented here, the goal of making possible a gradual transition into retirement for elderly workers and a gradual adjustment to their welfare rights level appears feasible; moreover, it is compatible with the further goal of reducing the financial burden on old age pensions by increasing the retirement age and thereby shortening the retirement period.

\subsubsection{Problems of part-time employment from the perspective of the firm}

a) In 1986 the share of part-time workers in the total number of workers in the Federal Republic was approximately 12.6 percent. ${ }^{116}$ This percentage is substantially greater in other countries; USA - 14.4 percent; Great Britain - 19.1 percent; Denmark - 23.7 percent; Sweden - 25.4 percent; and Norway - 30 percent. In the Federal Republic, part-time employment is concentrated in branches with high female participation rates, and almost 92 percent of all part-time employees are women.

b) The reason for the relatively small proportion of part-time work lies not only in the lack of employee interest, but also in employer reservations, not the least of which is related to the somewhat higher costs occurred. According to a study by the Bundesvereinigung der Deutschen Arbeitgeberverbände the extra costs resulting from two part-time employees

\footnotetext{
114 Cf. Schüle (1988), p. 48 ff.

115 This is the essence of the proposal by Kreikebohm (1986), p. $234 \mathrm{ff}$; on this problem cf. also Schüle (1988), p. 51.

${ }^{116}$ BDA (1987), p. 8; this reference is also applicable to the subsequent statistics.
} 
sharing a full-time job amount to approximately 3 percent. These include administrative costs, welfare costs, and costs due to inefficiency. ${ }^{117}$ On the other hand, these extra costs are balanced by the higher employee motivation, lower absenteeism, and a generally higher productivity. In addition, the chance for a better capacity utilization may result if part-time jobs are not interpreted in terms of simple job splitting.

Prerequisites for the introduction of part-time employment are the divisibility of duties, but also the awareness of the necessity of introducing part-time employment, in spite of certain obstacles. The resistance to new, more flexible forms of structuring employment, as shown through the introduction of flexibility in the wage contracts of the metal industry in 1984, for example, is not negligible. ${ }^{118}$ In this case, the resistance is almost exclusively found in the organizational difficulties of unions with respect to part-time employment.

Results based on previous surveys on job sharing - as conducted e.g. by the Ifo Institute - point to a figure of up to one million which is probably on the low end of actual longterm potential. The hundred-year history of many industrial branches probably substantially influenced the answer received in such surveys. It can be expected that under pressure of the future labour market, business will react with more flexibility as is currently the case and as is normally believed possible. Employees and their organizations cannot afford to close their minds to change in a permanent way.

It is important for further considerations that good organization should make it possible for challenging jobs to be shared. This includes management positions, such as the shift manager for part-time shifts. Obviously, responsibility cannot be shared, but it can often be defined in greater detail than it is commonly assumed.

c) All in all, fundamental objections on the side of the employers have not been found. Even employers increasingly emphasize the advantages of employing part-time employees. It is however surprising that, according to some reports, responses among elderly workers should still be very reserved four years after interesting opportunities were created. At Siemens, from October 1982 to December 1986, only approximatly 2 percent of the potential eligible workers took advantage of the opportunities which were offered them. ${ }^{119}$ Apparently, new models require a longer trial period.

In the literature, ${ }^{120}$ attention is called to the fact that it would be advantageous for decision makers in the company to have more information over the effects of concrete slidingphase models on worker productivity. Here is where appropriate analysis are called for.

\subsubsection{Comments on the necessity to supplement flexible retirement transitions}

In the following sections it will be made clear in which way a model such as that presented here should be supported by the legislators as well as by the collective bargaining partners and company officials. However, these suggestions only aim to help avoid the pitfalls of this very complex topic.

117 Ibid., p. 12 ff; Cf. Stitzel in Schmähl (1988), p. 232 ff. for an extensive discussion of costs in a mixed-financing programme.

118 Cf. Göbel (1986).

119 Cf. results reported by Schusser in Schmähl (1988), p. 213 ff. (218 ff.).

${ }^{120}$ Cf. Stitzel in Schmähl (1988), p. 236. 


\subsubsection{Legislative support for flexible transition}

a) in the above discussion, flex-models were introduced in which employers had the right to a longer "free phase" which was compensated for in other months by fulltime work. According to $\S 311$, Section 1, No. 1 RVO, if employment relationship continues without monetary compensation, membership in the Federal Health Insurance Plan may be retained but for three weeks at most. This provision has posed an obstacle to many reform plans in practice. ${ }^{121}$ Here is a prime opportunity for legislators to pass effective new rules to eliminate structural obstacles.

b) The necessity for actuarial reductions of partial pension claims before attainment of the legal retirement age is also justifiable. Without such reductions there would be no incentive to extend the flexible-transition phase beyond the legal retirement age. Such reductions imply income cuts if working life is prolonged.

c) The problem of partial pensions and maximum allowable earnings has already been addressed. This discussion also applies to the areas of partial pensions and Female Old Age Pensions during a specific transition period.

\subsubsection{Support from collective bargaining partners}

This area is significant when it is a matter of creating a sufficient number of part-time jobs. The feasibility of relevant regulations within the framework of company law remains, however, to be seen. This would be of particular interest for the purpose of formulating flex-models which would be suited to the particular requirements of individual companies. The extent to which the Federal Labour Court may support and encourage this through a recent decision remains to be seen. ${ }^{122}$ The decision was about a situation in which collective agreements explicitly authorized complementary firm-specific agreements about different working hours.

Especially important is the commitment of collective bargaining partners to the creation of a sufficient number of part-time jobs. This is crucial, as legislative instances cannot grant elderly employees a legal claim to a transition to part-time employment. This would imply broad intervention in private autonomy, and thereby a breach of Art. 2 GG. For, if not enough part-time jobs were available, the problem could thus arise that employees who could previously have claimed flexible old age pensions would be compelled to work until age 65 , in spite of the de jure existence of a partial pension model.

However, the authors are of the opinion that in the light of the sharp awareness of the problem on the part of employers, in the next twenty or thirty years the necessary conditions for implementing this model will be fulfilled.

\subsection{On the criticism of longer lifetime employment and on doubts about the partial pension model}

\subsubsection{Arguments against prolonging lifetime employment}

There are two basic lines of argument against lengthening the number of years of gainful employment. The first addresses present labour market conditions, and the second, the

121 Cf. Schusser in Schmähl (1988), p. 223 ff. with respect to the Siemens Model.

122 Ruling of August 18, 1987, NZA 1987, 779 ff.; cf. also Hoyningen-Huene/Meier-Krenz, NZA $1987,793 \mathrm{ff}$. on the problem addressed here. 
poor health frequently found among elderly workers. The latter has already been discussed rather extensively in the Gerontological Approach. Its credibility appears even weaker if one considers this concept of a longer working life in the light of the suggestion for a flexible transition into retirement. Moreover, it must be pointed out that in this area the critics themselves admit and even suggest differentiated points of view. ${ }^{123}$ For this reason it is not necessary to restate the arguments regarding health problems.

The criticism is, therefore, confined to the labour market argument. The core of this argument is that in the light of a current unemployment level of approximately 2.2 million people, lengthening the employment period, and thereby eliminating jobs, cannot even be considered. A substantial proportion of these unemployed persons are those entering retirement prematurely. Therefore, a reduction of this burden is first to be expected when the situation on the labour market is better. This argument can be objected to on the grounds that the proposal for lengthening the number of years of employment is based on data presented at the beginning of this study. According to these data, beginning in the year 2000 , even the most pessimistic models estimate a reduction in unemployment. Should this expectation prove false ${ }^{124}$ - in spite of expert opinion to the contrary - then the legislative instance still retains the option given a totally different situation, to delay enactment of laws which have been passed. Once more, it should be emphasized, however, that this doesn't need to be seriously considered. ${ }^{125}$

Another aspect must also be pointed out. The labour market is becoming increasingly split. On the one hand, jobs are not easy to find for a large number of unskilled and semiskilled workers. This is fundamentally the consequence of a structural change within the economy. On the other hand, there is an obvious shortage of qualified employees. For this reason, even in spite of high unemployment there can still be a need for qualified, experienced workers to offset this labour shortage. The criticism based on labour market problems appears therefore not very convincing even at the present moment.

The objections to partial pension models should be given serious consideration at the earliest possible time. This should then be reflected in the prolongation of employment time and, simultaneously, in the creation of opportunities for gradual transition from employment to retirement on the basis of a partial pension model. It is, therefore, the opinion of the authors that legislators should begin as soon as possible with the task of enacting appropriate measures, as set forth in this study.

\subsubsection{Doubts about the partial-pension model}

In all previous favourable presentations of a flexible transition model, caution has nevertheless also been called for regarding certain aspects of partial pension models. Because these precautions are in no way associated with fundamental objections and

123 Cf. the explanation in Bäcker/Steffen (1988), p. 165-167.

124 This opinion is held by Bäcker/Steffen (1988), p. 159, although it is not further elucidated in their text. Instead, the exclusively call for active employment policies.

125 Cf. Möschel, FAZ (May 14, 1988, p. 13; (from the mid-nineties) cf. also Sozialbeirat (1986), p. 20, and Franke in GVG (1988), p. 19 ff. 
pertain partially to special aspects of the BfA Model which are not present in the model proposed in this study, they will be mentioned in this section very briefly. 126

Those reservations specific to the BfA Model include misgivings regarding:

- further acceptance of a legal retirement age of 63 years and

- further financial burdens in the initial phase, as this would cast doubts on the cost-neutrality of the BfA partial pension model.

The following warnings are of a more general nature:

- the part-time labour market has a structure which renders the partial pension model a "sample of no commercial value",

- the danger exists that many workers will turn to disability pensions to avoid later benefit reductions,

- part-time employment among the elderly with partial pensions will appear as a third category in the group including other covered workers and part-time employees earning or working less than a minimum specified amount.

The issue of the structure of part-time work as an obstacle to any flexible transition model has been discussed extensively in previous sections (II/3 above). In closing, it would be remiss to assume that the present structure of the labour market will continue as it is now into the future and that employer/employee relations will remain inflexible indefinitely.

An evasion via disability pensions must be legally combatted in every model in which increasing the retirement age is proposed. This is due to the assumption that the ultimate goal cannot be reached through labour market self-regulation alone.

126 Of specific interest is a presentation by Tegtmeier at a GVG workshop to the topic, "Making the Retirement Age Flexible"; cf. GVG (1988), p. $16 \mathrm{ff}$. 


\section{REFERENCES}

BÄCKER, G. and STEFFEN, J. Alterssicherung in der Zukunft, Hamburg 1988.

BRACKMANN, K. Handbuch der Sozialversicherung, Vol. III, St. Augustin, loose leaf legislation, effective: August 1987

BITTELMEYER, G., HEGNER, F. and KRAMER, U. Bewegliche Zeitgestaltung im Betrieb, 2d ed., Cologne 1987.

BLEY, H. Sozialrecht, 5th ed., Frankfurt a. M. 1986.

BORCHERT, E.-J. Die Berücksichtigung familiärer Kindererziehung im Recht der gesetzlichen Rentenversicherung, Berlin 1981

BRÜCKNER, E. and MAYER, K. U. Lebensgeschichte und Austritt aus der Erwerbstätigkeit im Alter - am Beispiel der Geburtsjahrgänge 1919 - 1921, Working Paper No. 228 of the SFB 3, Frankfurt a. M. 1987.

Bundesminister für Arbeit und Sozialordnung (ed.) Bestandsaufnahme und Bewertung praktizierter Modelle zu vorgezogenen Ruhestandsregelungen, Bonn 1987, (cited as: Bundesminister für Arbeit und Sozialordnung (1987a)).

Bundesminister für Arbeit und Sozialordnung (ed.) Statistisches Taschenbuch 1987 - Arbeits- und Sozialstatistik, Bonn 1987, (cited as: Bundesminister für Arbeit und Sozialordnung (1987b)).

Bundesministerium für Wirtschaft (ed.) Wirtschaftspolitische Implikationen eines Bevölkerungsrückgangs, Gutachten des Wissenschaftlichen Beirats beim Bundesministerium für Wirtschaft, BMWi Studienreihe 28, Bonn 1980.

Bundesministerium für Wirtschaft (ed.) Kennzahlen zur gesamtwirtschaftlichen Entwicklung, Bonn 1987.

Bundesregierung Die Situation der älteren Menschen in der Familie - Vierter Familienbericht - Stellungnahme zum Bericht der Sachverständigenkommission für den vierten Familienbericht, Bundestagsdrucksache No. 10/6145, p. I - IX.

Bundesregierung Bulletin der Bundesregierung, No. 27/205 ff., 3.19.1987.

Bundesvereinigung der Deutschen Arbeitgeberverbände (ed.) Flexible Teilzeitarbeit, Cologne 1987.

CONRADI, H., JACOBS, K. and SCHMÄHL, W. "Vorzeitiger Rentenbezug in der Bundesrepublik Deutschland" in Sozialer Fortschritt, 1987, p. 182 ff.

Deutscher Bundestag Bericht über die Entwicklung in der Bundesrepublik Deutschland, Bundestagsdrucksache No. 10/863, 1.5.1984.

DINKEL, R. "Lebensarbeitszeitveränderung als Element einer Strukturreform der Rentenversicherung", in Sozialer Fortschritt, 1986, p. 241 ff.

DOETSCH, W. "Maßnahmen zur Anpassung der gesetzlichen Rentenversicherung an die sich verändernden Rahmenbedingungen", in Zeitschrift der Deutschen Rentenversicherungsträger, 1987, p. $509 \mathrm{ff}$.

ERLENK ÄMPER, A. Sozialrecht, 1st ed., Cologne 1984.

Evangelische Kirche in Deutschland (Kammer für soziale Ordnung) Alterssicherung - die Notwendigkeit einer Neuordnung. Eine Denkschrift, Gütersloh 1987, (cited as: EKD - Denkschrift).

Gesamtmetall (RIEK, W.) Modernes Arbeitszeitmanagement, advertisement in Frankfurter Allgemeine Zeitung, 1.12.1988, p. 20-23 (several articles by several authors).

Gesellschaft für Sozialen Fortschritt e.V. Bevölkerungsentwicklung und nachwachsende Gerteration. Report of a Arbeitskreis of the Gesellschaft für Sozialen Fortschritt, Bonn 1980.

Gesellschaft für Versicherungswissenschaft und -gestaltung e.V. (ed.) Flexibilisierung der Altersgrenzen, Bergisch-Gladbach 1988, (cited as: author's name in: GVG). 
GIBBS, R. NANCY "Grays on the 60" in Time magazine, 2.22.1988, p. 42-47.

GINIGER, S., DISPERZIERI, A. and EISENBERG J. "Older Workers in Speed and Skill Jobs" in Aging and Work, 1984, p. 7-12.

GLOMBIK, M. "15 Jahre flexible Altersgrenze in der Rentenversicherung” in Betriebs-Berater, 1987, p. 2027, (cited as: Glombik, BB 1987).

GLOMBIK, M. "Teilrentenmodell in der Rentenversicherung" in Betriebs-Berater, 1987, p. 2297 f. (cited as: Glombik, BB 1987).

GÖBEL, J. "Arbeitspolitik im Umbruch” in Der Arbeitgeber, No. 12 to 15, 1986.

GOOS, W. "Chemische Industrie: Bundestarifvertrag über Teilzeitarbeit vereinbart" (including collective bargaining text) in NZA 1987, p. $482 \mathrm{f}$.

GROHMANN, H. "Demographische Entwicklung und Finanzierung der Alterssicherung" in $P$. Hampe (ed.) Renten 2000: Längerfristige Finanzierungsprobleme der Alterssicherung und Lösungsansätze, Munich 1987, p. 22 ff.

GUTOWSKI, A. and HEGNER, F. Arbeitszeitpolitik im Strukturwandel von Wirtschaft und Gesellschaft, Cologne 1987.

HAIN, W. "Zur Abschätzung von finanziellen Auswirkungen geänderter Regelungen zur Altersgrenze in der gesetzlichen Rentenversicherung (GRV)" in Zeitschrift der Deutschen Rentenversicherungsträger, 1986, p. $213 \mathrm{ff}$.

HEGNER, F. and KRAMER, U. Neue Erfahrungen mit beweglichen Arbeitszeiten, Cologne 1988.

HERMANN, C. Gleichstellung der Frau und Rentenrecht, Berlin 1984.

HOYNINGEN-HUENE, G. v. and MEIER-KRENZ, U. "Mitbestimmung trotz Tarifvertrages? Tarifvorbehalt und Tarifvorrang in 77 III BetrVG" in NZA, 1987, p. $793 \mathrm{ff}$.

Ifo-Institut für Wirtschaftsforschung Betriebliche Altersversorgung, Munich 1988.

Institut für Demoskopie Allensbach "Rentenreform - Ja zu höheren Beiträgen, mehr Staatszuschuß und längerer Lebensarbeitszeit, nein zu gekürzten Bezügen und der staatlichen Grundrente", in Capital, No. 11, 1987, p. 149 f. (cited as: Allensbach-Institut (1987)).

Institut für Demoskopie Allensbach "Wann in den Ruhestand? Die Mehrzahl sagt nein" in Der Arbeitgeber, 1988, p. 240, (cited as: Allensbach-Institut (1988)).

JULITZ, L. "Die Union will mehr Teilzeitarbeit" in Frankfurter Allgemeine Zeitung, 3.24.1988, p. 14.

KLAUDER, W. "Längerfristige Arbeitsmarktperspektiven für die Bundesrepublik Deutschland" in J.-J. Hesse, H.-G. Rolff, C. Zöpel (eds) Zukunft und Bildungsperspektiven, Forum Zukunft, Vol. 3, Baden-Baden 1988, (cited as: Klauder (1988a)).

KLAUDER, W. Arbeitsmarkttendenzen der Zukunft; paper held at the conference "Zukunftsaufgabe Umweltbildung in Niedersachsen", Evangelische Akademie Loccum, published in the conference volume, May 1988, (cited as Klauder (1988b)).

KLAUDER, W. Welche Arbeitskräfte werden im Jahre 2000 gebraucht?, Stifterverband für die deutsche Wirtschaft e. V., Essen 1987.

Kommission of the EC Arbeitsmarktprobleme: Aussichten der Unternehmer und Arbeitnehmer, Brussels 1986.

KREIKEBOHM, R. Arbeitsmarkt und Alterssicherung, St. Augustin 1986.

KRUPP, H.-J. "Perspektiven einer Strukturreform der sozialen Alterssicherung" in Aus Politik und Zeitgeschichte, No. B 35, 1987, p. 3-16, (cited as: Krupp (B 35/87)).

LAMPERT, H. "Der Einfluß einer Verkürzung der Wochenarbeitszeit auf die Rentenversicherung" in Sozialer Fortschritt, 1985, p. 224 ff.

LEHR, U. Psychologie des Altern, Heidelberg 1977, (cited as: Lehr (1977)). 
LEHR, U. Ist Frauenarbeit schädlich?, Zurich 1979, (cited as: Lehr (1979)).

LEHR, U. Arbeitszeitverkürzung - ist das human?, Cologne 1984, (cited as: Lehr (1984)).

LEHR, U. Zur Situation der älterwerdenden Frau, Munich 1987, (cited as: Lehr (1987a)).

LEHR, U. "Neue Erkenntnisse der Gerontologie und ihre Relevanz für eine soziale Betriebsgestaltung" in Deutsches Institut für Betriebswirtschaft e. V. and others (eds.) Betriebliche Altersversorgung 1987, Wiesbaden 1987, (cited as: Lehr (1987b)).

LEHR, U. "Vom Achtstundentag zum Nullstundentag” in Frankfurter Allgemeine Zeitung, 3.24.1988, p. 10, (cited as: Lehr (1988)).

MAYDELL, B. v. "Stufenweiser Übergang in den Ruhestand und Veränderung der Erwerbsphase" in W. Schmähl (ed.) Verkürzung oder Verlängerung der Erwerbsphase?, Tübingen 1988, p. $191 \mathrm{ff}$.

MEINHOLD, H. "Langfristprobleme der gesetzlichen Rentenversicherung" in P. Hampe (ed.) Renten 2000: Längerfristige Finanzierungsprobleme der Alterssicherung und Lösungsansätze, Munich 1985 , p. $15 \mathrm{ff}$.

MOHR, B. "Mit 60 wieder an die Uni” in Frankfurter Allgemeine Zeitung, 4.22.1988, p. 12.

MÖSCHEL, W. "Der Generationenvertrag wird brüchig" in Frankfurter Allgemeine Zeitung, 5.14.1988, p. 13.

MURMANN, H. and MELDER, H.-J. "Teilrente soll Übergang in Ruhestand erleichtern" in Kölner Stadtanzeiger, 2.3.1988.

MÜLLER, H.-W. “Zur Verkürzung der Rentenlaufzeiten - Möglichkeiten und finanzielle Konsequenzen" in Zeitschrift der Deutschen Rentenversicherungsträger, 1987, p. 30 ff.

MUTZ, K. "Versicherer verhielten sich zuerst abwartend und restriktiv" in Handelsblatt, 1.4.1988.

NEU, A. D. Entwicklungstendenzen auf dem Arbeitsmarkt und ihre Auswirkungen auf die Jugendkriminalität, Heidelberg 1984.

NIEMEYER, W. "Strukturreform der gesetzlichen Rentenversicherung - Vorstellungen im BMA -" in Aus Politik und Zeitgeschichte, No. B 35, 1987, p. 17-27, (cited as: Niemeyer (B 35/87)).

ORIOL, W. E. "Work and Retirement. Visible Issues at U.N. World Assembly on Aging" in Aging and Work, 1984, p. 13-20.

PROEBSTING, H. “Trendwende in der Bevölkerungsentwicklung 1986/87? in Deutsche Angestelltenversicherung, No. 2, 1988 , p. $60 \mathrm{ff}$.

Prognos AG - Basel Gesamtwirtschaftliche Entwicklung und gesetzliche Rentenversicherung vor dem Hintergrund einer schrumpfenden Bevölkerung, text volume, Basel 1987, (cited as: PrognosGutachten (1987)).

REIMANN, A. "Trend zur Frühverrentung noch ungebrochen" in Deutsche Angestelltenversicherung, No. 10,1985 , p. $406 \mathrm{ff}$.

SALOWSKY, H. and SEFFEN, A. "Arbeitslosigkeit verschärft Trend zur Frühverrentung" in Arbeit und Sozialpolitik, 1986, p. 17 ff., (cited as: Salowsky/Seffen (1986)).

Sachverständigenkommission der Bundesregierung Bericht für den Vierten Familienbericht, Bundestagsdrucksache No. 10/6145, p. 1-187.

SCHÄUBLE, W. “Älter und weniger” in Die politische Meinung, No. 236, Jan./Feb. 1987, p. 37 ff.

SCHMÄHL, W. Einkommensentwicklung und Einkommensverteilung im Lebenslauf, working paper No. 220 of the SFB 3, Frankfurt a. M. 1986, (cited as: Schmähl (1986)). 
SCHMÄHL, W. "Rentenzugangsalter und Finanzlage der Rentenversicherung" in Zeitschrift der Deutschen Rentenversicherungsträger, 1987, p. 2 ff., (cited as: Schmähl (DRV 1987)).

SCHMÄHL, W, (ed.) Verkürzung oder Verlängerung der Erwerbsphase? Zur Gestaltung des Übergangs vom Erwerbsleben in den Ruhestand in der Bundesrepublik Deutschland, Tübingen, 1988, (cited as: author's name in: Schmähl (1988)):

SCHMIDT, A. "Die Entwicklung der Rentenversicherung und der volkswirtschaftlichen Rahmenbedingungen bei Beibehaltung des geltenden Rechts und die Auswirkungen der von der Kommission vorgeschlagenen Maßnahmen" in Zeitschrift der Deutschen Rentenversicherungsträger, 1987, p. $499 \mathrm{ff}$.

SCHMIDT, A. "Die Rentenversicherung im Umfeld langfristiger demographischer und ökonomischer Entwicklung" in Zeitschrift der Deutschen Rentenversicherungsträger, 1988, p. 23 ff.

SCHÜLE, U. Flexibilisierung der Altersgrenzen, Cologne 1988.

Sozialbeirat Gutachten über eine Strukturreform zur längerfristigen finanziellen Konsolidierung und systematischen Fortentwicklung der gesetzlichen Rentenversicherung im Rahmen der gesamten Alterssicherung, Bundestagsdrucksache No. 10/5352, p. 1 ff., (cited as: Sozialbeirat (1986)).

STARK, J. "Teilzeitarbeit in der Bundesrepublik Deutschland und in anderen OECD-Ländern" in Sozialer Fortschritt, 1987.

Statistisches Bundesamt Bevölkerung gestern, heute und morgen, Mainz 1985.

STEINJAN, W. "Alterssicherung in der Diskussion" in Sozialer Fortschritt, 1981, p. 268 ff.

TAUFEXIS, A. "Older - but coming on strong" in Time magazine, 2.22.1988, p. 48-50.

THOMAE, H. and LEHR, U. Berufliche Leistungsfähigkeit im mittleren und höheren Erwachsenenalter, Göttingen 1973.

TIETMEYER, H. Wirtschafts-, gesellschafts- und finanzpolitische Perspektiven, opening speech at the Geschäftsführerkonferenz der BDA, 5.22.1986, excerpt (p. 17 ff.).

Verband Deutscher Rentenversicherungsträger (Kommission des VDR) Zur langfristigen Entwicklung der gesetzlichen Rentenversicherung, Frankfurt a. M. 1987, (cited as: VDR-Gutachten).

WAGNER, G. Bestimmungsgründe und Konsequenzen des Rentenzugangsalters, working paper No. 226 of the SFB 3, Frankfurt a. M. 1986, (cited as: Wagner (1986)).

WAGNER, G. "Die Strukturreform der gesetzlichen Rentenversicherung und Strategien der Arbeitsmarktpolitik" in Sozialer Fortschritt, 1986, p. 245 ff., (cited as: Wagner Sozialer Fortschritt (1986)).

WINGEN, M. "Fördern, steuern nicht bevormunden - Was von einer Familienpolitik im ordnungspolitischen Sinn erwartet werden kann" in Frankfurter Allgemeine Zeitung, 4.21.1988, p. 8. 